\title{
Distinct transcriptomic features are associated with transitional and mature B-cell populations in the mouse spleen
}

\section{Eden Kleiman ${ }^{1}$, Daria Salyakina ${ }^{2}$, Magali De Heusch ${ }^{3,4}$, Kristen L. Hoek ${ }^{5}$, Joan M. Llanes ${ }^{5}$, Iris Castro ${ }^{1}$, Jacqueline A. Wright ${ }^{1}$, Emily S. Clark ${ }^{1}$, Derek M. Dykxhoorn ${ }^{6}$, Enrico Capobianco ${ }^{2}$, Akiko Takeda $^{7}$, Ryan M. McCormack ${ }^{1}$, Eckhard R. Podack ${ }^{1}$, Jean-Christophe Renauld ${ }^{3,4}$ and Wasif N. Khan ${ }^{1 *}$}

\author{
${ }^{1}$ Department of Microbiology and Immunology, Miller School of Medicine, University of Miami, Miami, FL, USA \\ ${ }^{2}$ Center for Computational Science, University of Miami, Miami, FL, USA \\ ${ }^{3}$ Ludwig Institute for Cancer Research, Brussels Branch, Brussels, Belgium \\ ${ }^{4}$ de Duve Institute, Université Catholique de Louvain, Brussels, Belgium \\ ${ }^{5}$ Department of Pathology, Microbiology and Immunology, Vanderbilt University School of Medicine, Nashville, TN, USA \\ ${ }^{6}$ Hussman Institute for Human Genomics, University of Miami, Miami, FL, USA \\ ${ }^{7}$ Department of Pathology and Immunology, Washington University School of Medicine in St. Louis, St. Louis, MO, USA
}

\section{Edited by:}

Paolo Casali, University of Texas Health Science Center, USA

Reviewed by:

Roberta Pelanda, University of Colorado Denver, USA

Hong Zan, University of Texas Health

Science Center, USA

\section{${ }^{*}$ Correspondence:}

Wasif N. Khan, Department of

Microbiology and Immunology,

University of Miami Miller School of

Medicine, 1600 Northwest 10th

Avenue, Miami, FL 33136, USA

e-mail:wnkhan@med.miami.edu

\begin{abstract}
Splenic transitional B-cells (T1 and T2) are selected to avoid self-reactivity and to safeguard against autoimmunity, then differentiate into mature follicular (FO-I and FO-II) and marginal zone (MZ) subsets. Transcriptomic analysis by RNA-seq of the five B-cell subsets revealed T1 cell signature genes included RAG suggesting a potential for receptor revision. T1 to T2 B-cell differentiation was marked by a switch from Myb to Myc, increased expression of the PI3K adapter DAP10 and MHC class II. FO-II may be an intermediate in FO-I differentiation and may also become MZ B-cells as suggested by principle component analysis. $\mathrm{MZ}$ B-cells possessed the most distinct transcriptome including down-regulation of CD45 phosphatase-associated protein (CD45-AP/PTPRC-AP), as well as upregulation of IL-9R and innate molecules TLR3, TLR7, and bactericidal Perforin-2 (MPEG1). Among the endosomal TLRs, stimulation viaTLR3 further enhanced Perforin-2 expression exclusively in MZ B-cells. Using gene-deleted and overexpressing transgenic mice we show that IL-9/IL-9R interaction resulted in rapid activation of STAT1, 3, and 5, primarily in MZ B-cells. Importantly, CD45-AP mutant mice had reduced transitional and increased mature $\mathrm{MZ}$ and FO B-cells, suggesting that it prevents premature entry of transitional B-cells to the mature B-cell pool or their survival and proliferation. Together, these findings suggest, developmental plasticity among splenic B-cell subsets, potential for receptor revision in peripheral tolerance whereas enhanced metabolism coincides with T2 to mature B-cell differentiation. Further, unique core transcriptional signatures in $\mathrm{MZ} \mathrm{B}$-cells may control their innate features.
\end{abstract}

Keywords: transcriptome by RNA-seq technique, splenic transitional B-cells, follicular 1 and 2 B-cells, marginal zone B-cells, DAP10 PI3K pathway, IL-9/IL-9R, Myb Myc, Toll-like receptors 3 and 7

\section{INTRODUCTION}

The role of B-lymphocytes is to produce antigen specific antibodies to neutralize pathogens. B-cells develop in the bone marrow (BM) where most autoreactive clones are triaged by the central tolerance mechanisms of clonal deletion, anergy, or receptor editing (1). Surviving sIgM ${ }^{+}$immature or transitional 1 (T1) B-cells migrate to the spleen, where they are again tested for autoreactivity. Innocuous clones are allowed to develop into transitional 2 (T2) cells (2). Observations that T1 cells are extremely sensitive to BCR-induced apoptosis in vitro suggest that the T1-stage serves as a peripheral tolerance checkpoint (3-7). Dysregulation of peripheral checkpoint can lead to autoimmune pathologies such as SLE, RA, and MS (8-10).

The immature $\mathrm{T} 2$ cell stage is believed to serve as the branching point for selection into functionally distinct mature B-cell subsets comprised of follicular I and II (FO-I and FO-II), B1, and marginal zone (MZ) B-cell compartments [reviewed in Ref. (11)]. FO-I cells specialize in $\mathrm{T}$ cell-dependent (TD) immune responses whereas MZ B-cells specialize in rapid T cell-independent (TI) antibody responses and possess innate-like properties (11-13). The function of the FO-II subset is unknown (14). A comprehensive analysis to identify transcriptional changes associated with peripheral tolerance at the transitional stages and functional specialization of mature B-cell subsets may provide a framework for hypothesisdriven experiments to identify key processes responsible for B-cell biological properties.

The Immunological Genome consortia (ImmGen) has provided a rich resource for gene expression data sets to the immunological community including all known mouse B-cell subsets using microarray. Analyses of these gene expression data sets have 
produced gene-network models laying the foundation for experimentally testable hypotheses for various hematopoietic lineage cell developmental relationships and acquisition of functional specialization. However, such analysis has not been reported for the $\mathrm{B}$ lineage. Here, we report bioinformatics analysis performed on data obtained with next generation sequencing (NGS) on highly purified B-cell subsets that are either not available from ImmGen (FoB-II) or were phenotypically defined differently than the current study. Our splenic B-cell populations were enriched using a combination of schemes and to achieve maximum cell homogeneity defined as; $\mathrm{T}^{21 / 23 \mathrm{DN}}\left(\mathrm{B} 220^{+}, \mathrm{AA} 4.1^{+}, \mathrm{CD}^{2} 3^{-}, \mathrm{CD} 21^{-}\right.$, $\left.\mathrm{CD} 24^{\mathrm{hi}}\right), \mathrm{T}^{\mathrm{CD} 21 \text { int }}\left(\mathrm{B} 220^{+}, \mathrm{AA} 4.1^{+}, \mathrm{CD} 23^{+}, \mathrm{CD} 21^{\mathrm{int}}, \mathrm{CD} 24^{\mathrm{hi}}\right)$, FO-I $\left(\mathrm{B} 220^{+}, \mathrm{IgM}^{\mathrm{lo}}, \mathrm{CD} 21^{\text {int }}, \mathrm{IgD}^{+}, \mathrm{CD} 23^{+}, \mathrm{CD} 24^{\mathrm{lo}}, \mathrm{CD} 9^{-}\right), \mathrm{FO}-$ II $\left(\mathrm{B} 220^{+}, \mathrm{IgM}^{\mathrm{hi}}, \mathrm{CD} 21^{\mathrm{int}}, \mathrm{IgD}^{+}, \mathrm{CD} 23^{+}, \mathrm{CD} 24^{\mathrm{lo}}, \mathrm{CD} 9^{-}\right)$, and $\mathrm{MZ}^{\mathrm{CD}} 9+\left(\mathrm{B} 220^{+}, \mathrm{IgM}^{\mathrm{hi}}, \mathrm{CD} 21^{\mathrm{hi}}, \mathrm{IgD}^{-}, \mathrm{CD} 23^{-}, \mathrm{CD} 24^{\mathrm{int}}, \mathrm{CD}^{+}\right)$.

We identified many novel stage-specific transcripts not identified by ImmGen data sets and associated processes. Our comparative analysis of transcriptomes in specific B-cell subsets has advanced our understanding of the transcriptional networks associated with peripheral B-cell development and selection as well as functional specialization acquired by mature B-cell subsets. We highlight transcripts contributing to innate $\mathrm{MZ}$ B-cell function (TLR3 and Perforin-2) and demonstrate a previously unknown function for IL-9R and CD45-AP in B-cells.

\section{MATERIALS AND METHODS \\ MICE}

C57BL/6 mice were purchased from The Jackson Laboratory and maintained at University of Miami animal facility. CD45- $A P^{-/-}$ (C57BL/6), IL-9R ${ }^{-/-}$, and IL-9 transgenic (Tg5) mice have been previously described (15-17). Unless indicated otherwise, mice used in these studies were aged between 6 and 10 weeks. These studies were approved by the Institutional Animal Care and Use Committee.

\section{FLOW CYTOMETRIC ANALYSIS AND CELL SORTING}

$\mathrm{CD} 3^{+}$enriched immature and $\mathrm{CD} 93^{+} \mathrm{CD} 43^{+}$depleted mature splenocytes were incubated with fluorochrome labeled antibodies to sort $\mathrm{T} 1^{21 / 23 \mathrm{DN}}, \mathrm{T} 2^{\mathrm{CD} 21 \mathrm{int}}, \mathrm{FO}-\mathrm{I}, \mathrm{FO}-\mathrm{II}$, and $\mathrm{MZ}^{\mathrm{CD} 9+}$ on a $\mathrm{BD}$ FACS Aria II yielding 95-99\% purity as described in Figure S1 in Supplementary Material. Briefly, B-cell enrichment was performed using Mouse B Lymphocyte Enrichment set-DM (BD Biosciences). Transitional B-cells were sorted from pooled splenocytes after two rounds of AA4.1 positive selection. Sorting from $\mathrm{DAPI}^{-}, \mathrm{B} 220^{+}$cells produced two relatively homogeneous transitional subsets. $\mathrm{T}^{21 / 23 \mathrm{DN}}$ were $\mathrm{AA} 4.1^{+}, \mathrm{CD} 23^{-}, \mathrm{CD} 21^{-}, \mathrm{CD} 24^{\mathrm{hi}}$, whereas $\mathrm{T}^{\mathrm{CD} 21 \text { int }}$ were $\mathrm{AA} 4.1^{+}, \mathrm{CD} 23^{+}, \mathrm{CD} 21^{\text {int }}, \mathrm{CD} 24^{\text {hi }}$. For mature B-cell sorting, pooled splenocytes were enriched for Bcells and simultaneously depleted of AA4.1 ${ }^{+}$(transitional) cells. Three purified mature B-cell populations were sorted from the $\mathrm{DAPI}^{-}, \mathrm{B}_{22}{ }^{+}$gate. FO-I were $\mathrm{IgM}^{\mathrm{lo}}, \mathrm{CD} 21^{\text {int }}, \mathrm{IgD}^{+}, \mathrm{CD}_{2}{ }^{+}$, $\mathrm{CD} 24^{\text {lo }}$, and $\mathrm{CD}^{-}$. FO-II were $\mathrm{IgM}^{\text {hi }}, \mathrm{CD} 21^{\text {int }}, \mathrm{IgD}^{+}, \mathrm{CD}^{2} 3^{+}$, $\mathrm{CD} 24^{\mathrm{lo}}$, and $\mathrm{CD}^{-} \cdot \mathrm{MZ}^{\mathrm{CD} 9+}$ were $\operatorname{IgM}^{\mathrm{hi}}, \mathrm{CD} 21^{\mathrm{hi}}, \mathrm{IgD}^{-}, \mathrm{CD}^{-} 3^{-}$, $\mathrm{CD} 24^{\text {int }}$, and $\mathrm{CD}^{+}$.

Flow cytometric analysis of splenocytes from CD45-APdeficient mice and IL-9R ${ }^{-/-} /$IL-9 transgenic were performed on a LSRII Flow cytometer and LSR Fortessa, respectively (BD
Bioscience). For intracellular staining, cells were stimulated $15 \mathrm{~min}$ with IL-9 for $15 \mathrm{~min}$. Cells were then fixed $10 \mathrm{~min}$ in 2\% PFA, 90\% methanol permeabilized (30 min), washed extensively, blocked and then incubated $1 \mathrm{~h}$ with anti-pSTAT, and surface marker antibodies. FCM data were analyzed using FlowJo software (TreeStar). Antibodies used are listed as follows; CD93 Biotin Clone AA4.1, CD23 PE/Biotin Clone B3B4, CD21 FITC/PE Clone 7G6, Streptavidin PE Cy7, B220 V500 Clone RA3-6B2, CD19 Clone 1D3, CD9 Biotin Clone KCM8, pSTAT3 (pY705) Alexa Fluor 647 Clone 4/pSTAT3, pSTAT1 (pY701) Alexa Fluor 647 Clone 4a, pSTAT5 (pY694) Alexa Fluor 647 Clone 47/Stat5 (pY694) (BD Bioscience), CD93 APC Clone AA4.1, CD24 PerCP Cy5.5 Clone M1/69, IgD PacBlue Clone 11-26 (eBioscience), B220 Alexa 700 Clone RA36B2, Streptavidin PerCP (Biolegend), IgM 649 Fab Fragment (Jackson ImmunoResearch), CD9 FITC Clone MZ3 (Santa Cruz Biotechnology), DAPI (Invitrogen). B220 Alexa 700, CD9 Biotin, Streptavidin PerCP, and pSTAT antibodies were used for IL-9R/IL9 studies. CD21 Clone 7G6 is used for both sorting and IL-9R/IL-9 studies.

\section{RNA ISOLATION FOR NEXT GENERATION SEOUENCING AND ANALYSIS}

RNA was prepared from the sorted cells using Qiagen RLT buffer. PolyA RNA was selected and library constructed using Illumina RNA sample preparation reagents following manufacturer's recommendations (Illumina). RNA integrity was assessed using a Bioanalyzer 2100 (Agilent) as well as Nanodrop 8000 Spectrophotometer (Thermo Scientific). Four of the five samples were sequenced on the Illumina GAIIx using Cluster Generation Kit v4 and Sequencing Kit v4, generating 74 base single-end reads. The fifth sample ( $\mathrm{MZ}^{\mathrm{CD} 9+}$ ) was sequenced on the Illumina HiSeq2000 using the reagents provided in the Illumina TruSeq PE Cluster Kit v3 and the TruSeq SBS Kit - HS (200 cycle) kit, generating 99base paired-end reads. Read 2 was not used in this study and read1 was trimmed to match the 74 base reads generated by the GAIIx. Quality of the RNA-seq data was reviewed using FastQC software version $0.10 .1^{1}$. Average phred-like quality scores were $>30$ in all samples if calculated per-base and over 36 if calculated per sequence. This quality was considered sufficient and no reads were filtered out. All samples passed testing on basic parameters in FastQC (data not shown), except sequence duplication levels (Table S1 in Supplementary Material). Elevated duplication levels may arise in RNA-seq due to "over-sequencing" of high abundant transcripts as well as bias caused by non-random hexamer priming (18). We did not remove any duplicates because there is no consensus so far how it affects expression level estimations. Table S1 in Supplementary Material shows basic statistics on the samples.

Quantification of transcriptome was done in two steps as described in TopHat protocol (19). In the first step, TopHat was used to map the reads to the reference genome (UCSC build mm10 GRCm38 from September 2012) with default settings and novel splice discovery disabled. In the second step, Cufdiff was employed to calculate FPKM values using reference transcriptome along with BAM files from the first step for each sample. Data were analyzed in automated fashion on the cluster hosted by the

${ }^{1}$ http://www.bioinformatics.babraham.ac.uk/projects/fastqc/ 
High-Performance Computing core in the Center for Computational Science, University of Miami. All transcript expression below FPKM 1 was set to 1 . Quantitative FPKM values were $\log 2$ transformed and converted to Z-scores. miRNA, rRNA, and hemoglobin transcripts were removed from the analysis as these transcripts likely represented artifacts (20). Table S1 in Supplementary Material contains FPKM, log2 transformed FPKM, $z$-scores, and fold-change $(\mathrm{FC})$ relative to $\mathrm{T} 2{ }^{\mathrm{CD} 21 \text { int }}$.

RNA species compositions (biotypes) were analyzed and visualized using NOIseq package in Bioconductor ${ }^{2}$. Biotypes from Ensemble annotation were used (Figure S1 in Supplementary Material). Data analysis was performed using R software ${ }^{3}$. Scatterplot was generated using "pairs" R function. Principle component analysis (PCA) was performed with "prcomp" R function. $Z$-scores for gene expression were visualized as heatmaps using "heatmap.2" function from "gplots" R library. Venn diagrams were generated using "VennDiagram" library in R. Functional annotation clustering was done using DAVID bioinformatics online software (21, 22). Each term is ranked based on enrichment score along with corresponding $P$ value. Prioritization of clusters was based on enrichment score using highest stringency settings. GeneGo software (MetaCore, Thomson Reuters) was used to predict transcription factor $(\mathrm{TF})$ regulation during development. All differentially expressed (DE) genes $(\mathrm{FC}>2$ ) between two subsets (or signature genes) were used as input.

\section{REAL-TIME PCR}

RNA for quantitative Real-Time PCR (qRT-PCR) was isolated using RNeasy Minikit and reverse-transcribed utilizing Quantitect Reverse Transcription kit (Qiagen). qRT-PCR was performed with TaqMan Fast Universal PCR Master Mix in Step One Real-Time PCR System (Applied Biosystems). TaqMan primer/probes (Applied Biosystems) are as follow: Gfil Mm00515855_m1, Tlr3 Mm01207404_m1, Tlr7 Mm00446590_ m1, Tlr9 Mm00446193_m1, Rag1 Mm01270936_m1, Rag2 Mm01270938_m1, IL-9R Mm0043413_m1, Tnfrsf13c/BAFF-R Mm00840578_g1,Ptprc-ap/CD45-AP Mm01236556_m1,Mpeg1/ Perforin-2 Mm01222137_g1, Hcst/Dap10 Mm01270936_m1, Bmf Mm00506773_m1, IKKع Mm00444862_m1, Tnfrsf13b/TACI Mm00840182_m1, and Gapdh Mm99999915_g1.

\section{WESTERN BLOT}

T1, T2, and Mature B-cell (FO) subsets were sorted and westernblotted as previously described in Ref. (7). Briefly, $20 \mu \mathrm{g} / \mathrm{lane}$ of total cellular extracts from FACS cells were analyzed by immunoblotting with antibodies specific for the indicated antiapoptotic proteins. Anti-p38 was used as a loading control. Antibody information is as follows: Mcl-1 (Rockland Immunochemicals); Bcl-2, Bcl-xL, p38, Pim-2 (Santa Cruz Biotechnology); A1 (R\&D Systems); and c-IAP2 (Cell Signaling Technology).

\section{B-CELL ISOLATION FOR IN VITRO STIMULATION}

Splenic B-cells enriched by CD43 negative selection or CD45/B220 positive selection beads (BD Bioscience) were cultured (7) and

${ }^{2}$ http://www.bioconductor.org/

${ }^{3}$ http://www.r-project.org/ stimulated with Poly(I:C) (\#tlrl-pic), CL097 (\#tlrl-c97), or CpG (tlrl-1826) from Invivogen.

\section{STATISTICAL ANALYSIS}

Biological data were analyzed using Student's $t$-test. All data are represented as mean \pm SEM. Values of ${ }^{\star} P \leq 0.05$ were considered statistically significant. Analysis performed using Prism software (GraphPad).

\section{RESULTS}

TRANSCRIPTOME ANALYSIS REVEALS PREVIOUSLY UNKNOWN RELATIONSHIPS AMONG SPLENIC B-CELL SUBSETS

We FACS-purified five splenic B-cell subsets using a combination of schemes previously described for mouse and human B-cells (2, $4,6,14,23-25)$. This purification scheme was used to maximize homogeneity for RNA-Seq analysis (Figure S1 in Supplementary Material). Hereafter, B-cell subsets will be referred to as $\mathrm{T} 1^{21 / 23 \mathrm{DN}}$, $\mathrm{T}_{2}{ }^{\mathrm{CD} 21 \text { int }}$, FO-I, FO-II, and $\mathrm{MZ}^{\mathrm{CD} 9+}$ to denote distinction from other sorting schemes. As shown in Figures 1A,B, the NGS data corroborate well with cell-surface marker expression used in sorting thereby confirming both phenotype and purity. qPCR further verified the accuracy of our NGS data (Figures 2-9).

Transcriptome analysis yielded 10,851 unique transcripts among our subsets. Approximately 19\% (2057) of transcripts were up-regulated and $16.5 \%$ (1789) were down-regulated $(\mathrm{FC}>2)$ in at least one subset relative to $\mathrm{T} 2{ }^{\mathrm{CD} 21 \text { int }}$. This subset was used for comparison because of its central position between $\mathrm{T} 1^{21 / 23 \mathrm{DN}}$ and mature subsets. $\mathrm{MZ}^{\mathrm{CD} 9+}$ displayed the highest number of $\mathrm{DE}$ genes, whereas FO-II had the lowest (Figure 1C). There were significant differences in the number of DE genes detected in our data-set compared to ImmGen (Table S1 in Supplementary Material). For example, ImmGen identified seven genes higher in $\mathrm{T} 1$ versus $\mathrm{T} 2$ and 23 genes higher in $\mathrm{T} 2$ versus $\mathrm{T} 1$ ( $\mathrm{FC}>2$ cut-off). Our RNA-Seq data identified 375 genes higher in $\mathrm{T}^{21 / 23 \mathrm{DN}}$ versus $\mathrm{T} 2^{\mathrm{CD} 21 \text { int }}$ and 326 genes higher in $\mathrm{T} 2^{\mathrm{CD} 21 \text { int }}$ versus $\mathrm{T} 1^{21 / 23 \mathrm{DN}}$ (also FC $>2$ cut-off). This clearly demonstrates the utility and advantage of our sorting scheme as well as use of RNA-Seq technology.

Available information suggests that T1 differentiate into T2, which give rise to mature B-cells. To determine B-cell subset relationships, we used the number of DE genes $(\mathrm{FC}>2)$ to construct a distance graph, which suggested three additional differentiation paths (dashed lines): (1) $\mathrm{T}^{21 / 23 \mathrm{DN}}$ to $\mathrm{MZ}^{\mathrm{CD} 9+}$, (2) FO-II to FO-I, and (3) FO-II to MZ ${ }^{\mathrm{CD} 9+}$ (Figure 1D). Scatterplot and PCA analysis illustrates that among our subsets, $\mathrm{MZ}^{\mathrm{CD} 9+}$ was most closely related to FO-II. Surprisingly, $\mathrm{T}^{21 / 23 \mathrm{DN}}$ and $\mathrm{T} 2{ }^{\mathrm{CD} 21 \text { int }}$ were almost equally related to $\mathrm{MZ}^{\mathrm{CD} 9+}$ cells (Figures 1E,F). These three potential $\mathrm{MZ}^{\mathrm{CD} 9+}$ precursors shared significant overlap in $\mathrm{DE}$ genes relative to $\mathrm{MZ}^{\mathrm{CD} 9+}$ (Figure 1G). This analysis also shows that FOII are in the middle of a follicular differentiation pathway between $\mathrm{T} 2{ }^{\mathrm{CD} 21 \text { int }}$ and FO-I (Figures 1E,F). Consistently, there was a high degree of overlap in $\mathrm{DE}$ genes between $\mathrm{T} 2^{\mathrm{CD} 21 \text { int }}$ and FO-II or FO-I (Figure 1H).

DISTINCT TRANSCRIPTION PROGRAMS DEFINE TRANSITIONAL AND MATURE B-CELL SUBSETS

To systematically identify transcription regulators (TR) (TF plus regulatory genes) that control co-expression of $\mathrm{B}$-cell 
A

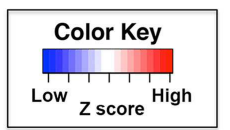

Cell surface markers

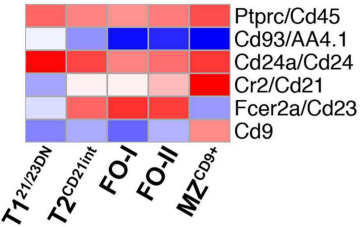

C

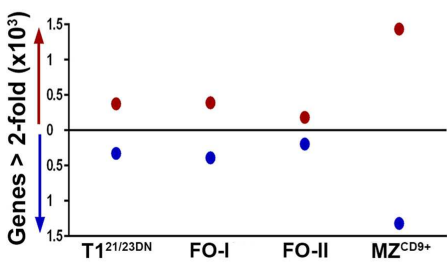

E

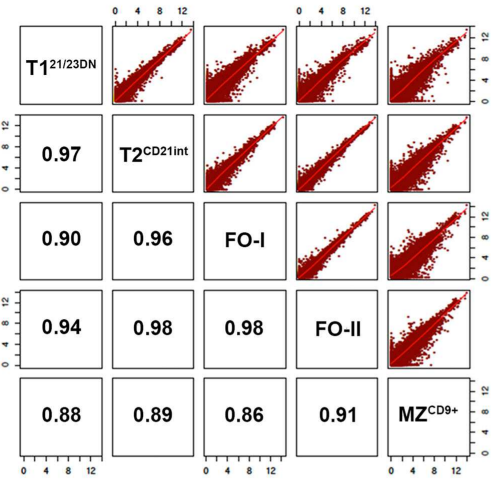

\section{G \\ G $\quad$ Number of}

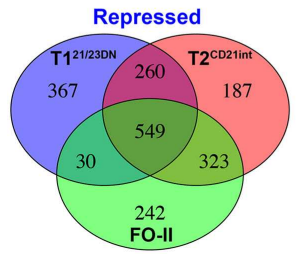

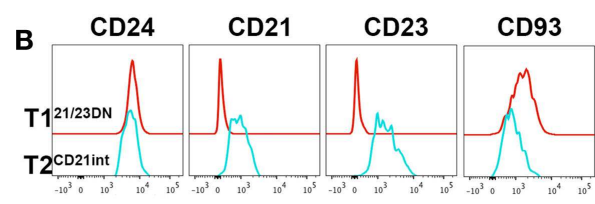
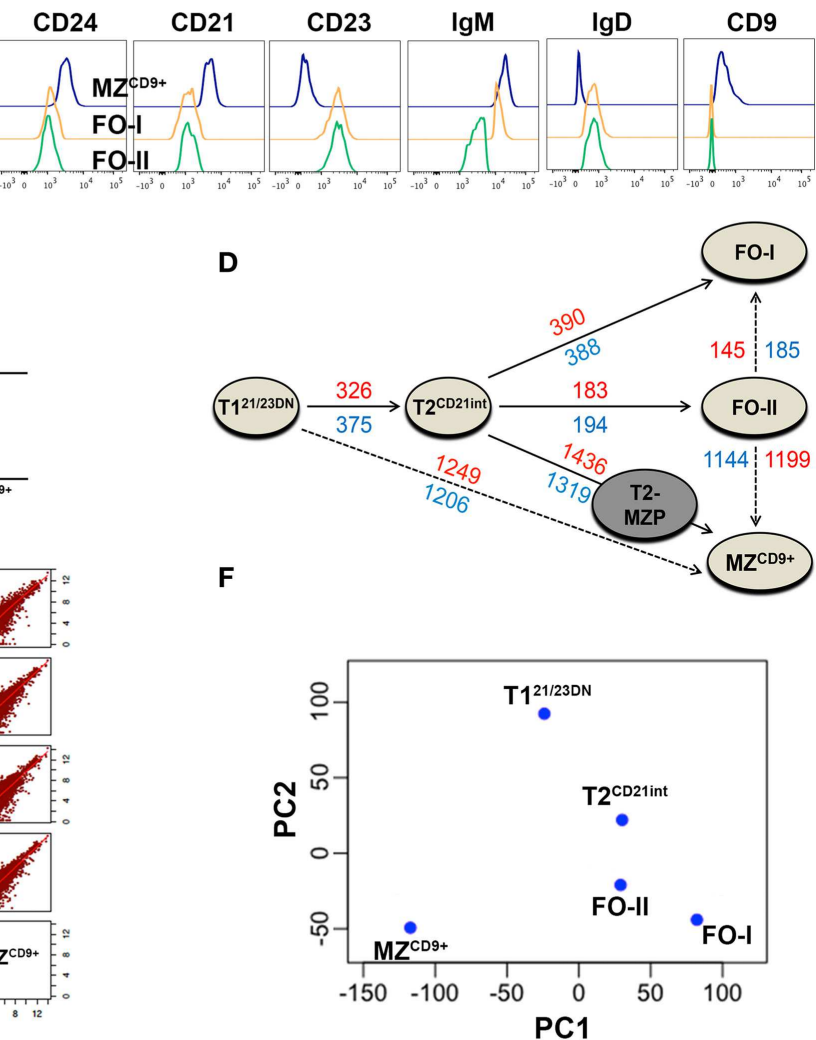

H Number of genes $(\mathrm{FC}>2)$ relative to $\mathrm{T}^{\mathrm{c} \text { (021int }}$
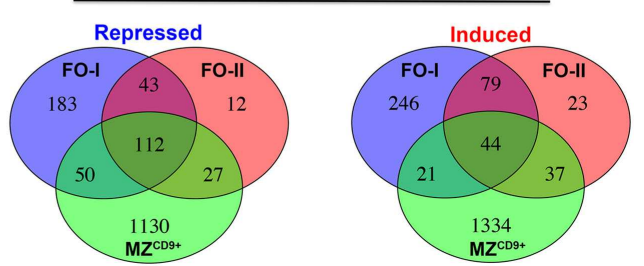

FIGURE 1 | Global gene expression profiles define hierarchical relationships among splenic B-cell subsets. (A) NGS results of gene expression profiles of each B-cell subset corroborate well with the cell-surface marker expression shown in (B). Heatmap displaying expression of mRNAs (median log-transformed relative fold-change) encoding cell-surface markers that define $\mathrm{T}^{21 / 23 \mathrm{DN}}, \mathrm{T} 2^{\mathrm{CD} 21 \mathrm{int}}$, FO-I, FO-II, and $\mathrm{MZ}^{\mathrm{CD} 9+} \mathrm{B}$-cell subsets and were used for cell sorting by FACS (see Figure S1 in Supplementary Material for details). Immunoglubulin sequences were excluded from NGS data analysis. Red color indicates high $z$-score (high expression) while blue indicates a low $z$-score (low expression). (B) Histograms depict cell-surface marker expression that define transitional (top panels) and mature (bottom panels) splenic B-cell subsets as in (A). (C) Graphic depiction of the number of genes differentially expressed (DE) relative to $2^{\mathrm{CD} 2 \text { lint }}(\mathrm{FC}>2$ ). Red circles (above horizontal line at 0 ) represent the number of up-regulated genes while the blue circles (below horizontal line at 0 ) represent the number of down-regulated genes. $1^{21 / 23 \mathrm{DN}}$, FO-I, FO-II, and $\mathrm{MZ}^{\mathrm{CD} 9+}$ had 6.46, 7.17, 3.74, and $25.39 \%$ DE genes (includes up- and down-regulated), respectively. (D), Distance plot indicating the number of up-regulated genes (red) and down-regulated genes (blue) in various maturation steps $(F C>2)$. Solid arrows indicate known paths of maturation whereas dotted arrows indicate alternate maturation paths predicted by NGS data analysis in this study. Although we did not sort T2-MZP (gray), it is included for completeness. It is believed to be an intermediate between T2 to MZ B-cell differentiation. (E) Scatterplot analysis of log-transformed NGS data showing similarity in global gene expression between all B-cell subsets. Numbers inside intersecting boxes indicate the percentage of similarity. Graphical representation of this percentage is displayed on upper panels where each red dot corresponds to a single gene. (F) Principle component analysis (PCA) using two principle components (PC1 and PC2) where PC1 explained the majority of gene expression differences followed by PC2. Similarity between B-cell subsets can be ascertained by the physical difference between circles on the plot. Both scatterplot and PCA analysis do not involve fold-change cut-offs and involve all subset cross comparisons. (G) The number of repressed or induced genes overlapping during differentiation from either $\mathrm{T} 1^{21 / 23 \mathrm{DN}}, \mathrm{T} 2^{\mathrm{CD} 21 \text { int }}$, or FO-II to $\mathrm{MZ}^{\mathrm{CD} 9+}$ cells. $\mathbf{( H )}$ The number of repressed or induced genes overlapping in differentiation from $\mathrm{T}_{2}^{\mathrm{CD} 21 \text { int }}$ to either $\mathrm{FO}-\mathrm{I}$, FO-II, or $\mathrm{MZ}^{\mathrm{CD} 9+}$ cells. 
A $T 1^{21 / 23 D N}>T 2^{C D 21 i n t}$

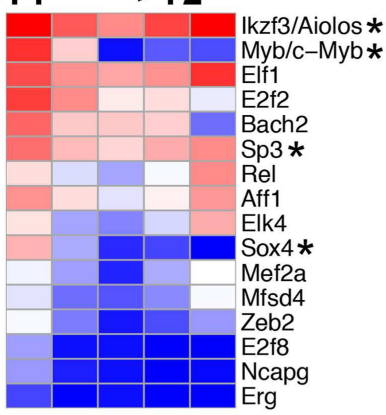

T2 ${ }^{\text {CD21int }}>T 1^{21 / 23 D N}$

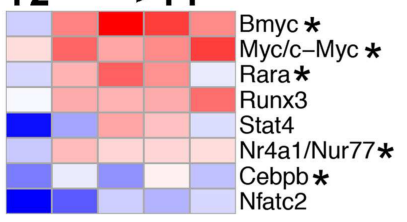

B Trans vs mature

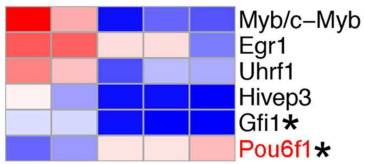

C FO>T2 ${ }^{\mathrm{CD} 21 \mathrm{int}}$
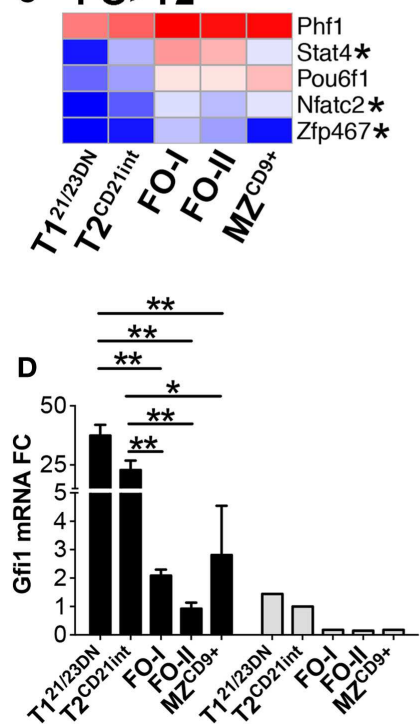

\section{$\mathrm{E} \mathrm{MZ}^{\mathrm{CD} 9+}>$ others}

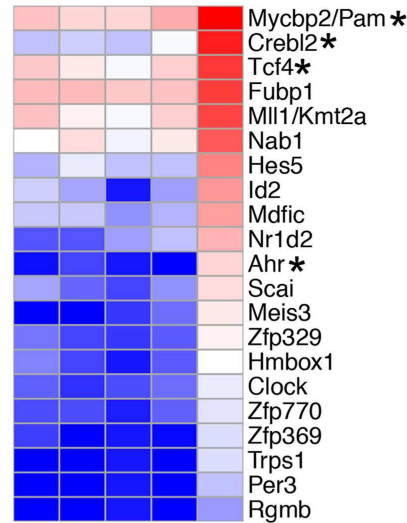

others $>\mathrm{MZ}^{\mathrm{CD} 9+}$

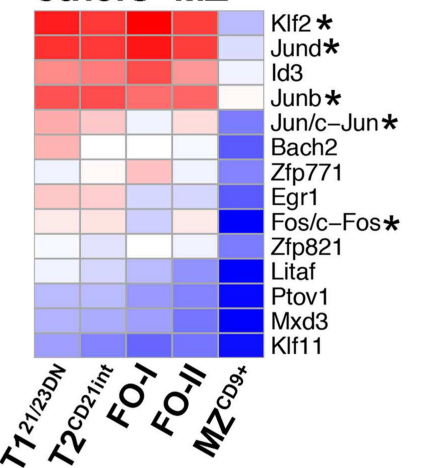

\section{F HDAC}

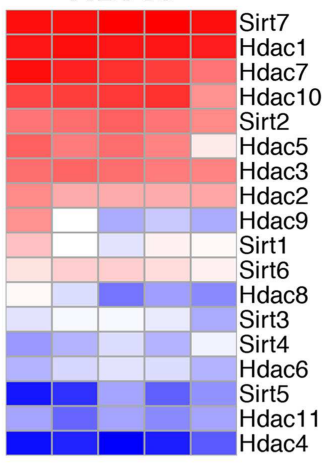

HAT
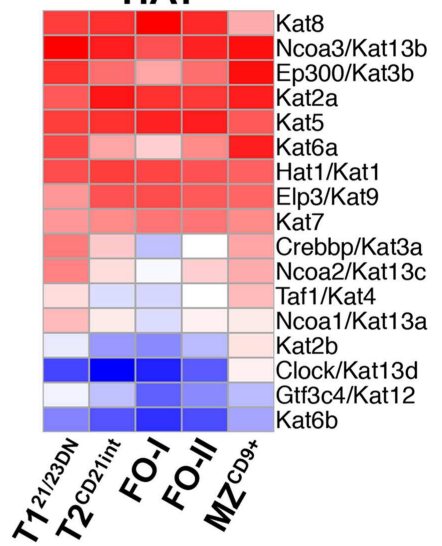

G

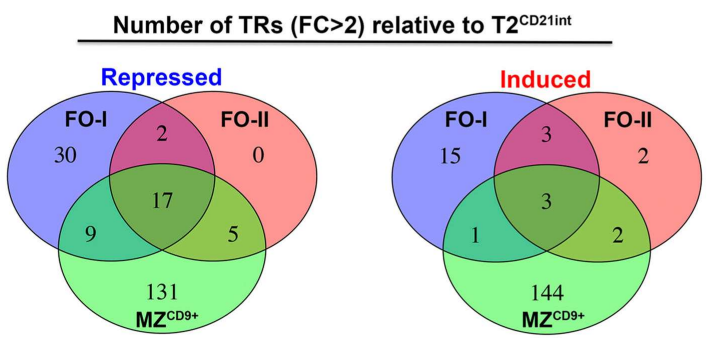

H

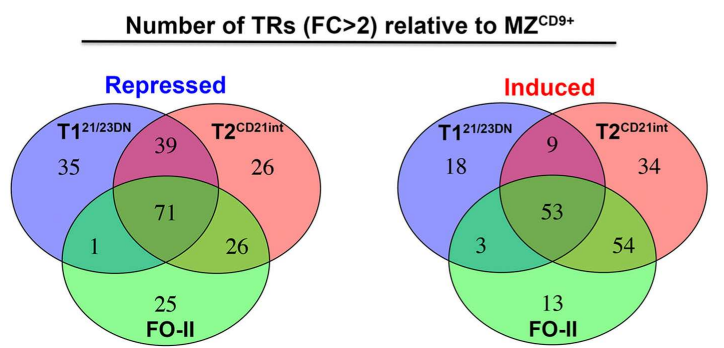

FIGURE 2 | Expression of distinct transcription regulators in splenic B-cell subsets. Heatmap display of NGS analysis of DE transcription regulators (including TFs) using $z$-scores comparing: (A) T1 $1^{21 / 23 D N}$ to $T 2^{\text {CD2 } 1 \text { int }}$

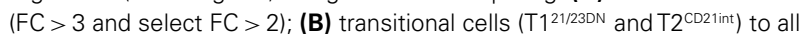
mature B-cells ( $F C>3$ ); (C) FO (FO-I and FO-II) to T2CD21int (FC > 2); and (E) $\mathrm{MZ}^{\mathrm{CD} 9+}$ to all other subsets ( $\mathrm{FC}>3$ ), up-regulated (top heatmap) and down-regulated (bottom heatmap). Pou6f1, the only gene over threefold higher in mature relative to transitional cells, is shown in red (B). Asterisks denote important genes discussed in the text. Many of the TFs shown are predicted to regulate genes that are DE in the B-cell subsets (refer to Table S3 in Supplementary Material). (D) Gfi1 is down-regulated during transitional to mature B-cell differentiation. qRT-PCR (black bars) validation of NGS results (gray bars). qRT-PCR data are representative of three independent experiments with FACS-sorted B-cell subsets, where each experiment utilized pooled splenocytes from 2 to 5 mice. ${ }^{*} P \leq 0.05$; ${ }^{*} P \leq 0.01$. (F) Heatmap display of transcripts encoding histone deacetylase (HDAC, top) and histone acetylase (HAT, bottom) enzymes. (G) The number of repressed or induced TRs that overlap during differentiation from $\mathrm{T}^{\mathrm{CD} 21 \text { 1int }}$ to either FO-I, FO-II, or $\mathrm{MZ}^{\mathrm{CD} 9+}$ cells. (H) The number of repressed or induced genes that overlap during differentiation from either $\mathrm{T} 1^{21 / 23 \mathrm{DN}}, \mathrm{T}^{\mathrm{CD} 21 \mathrm{int}}$, or FO-II to $\mathrm{MZ}^{\mathrm{CD} 9+}$ cells. 

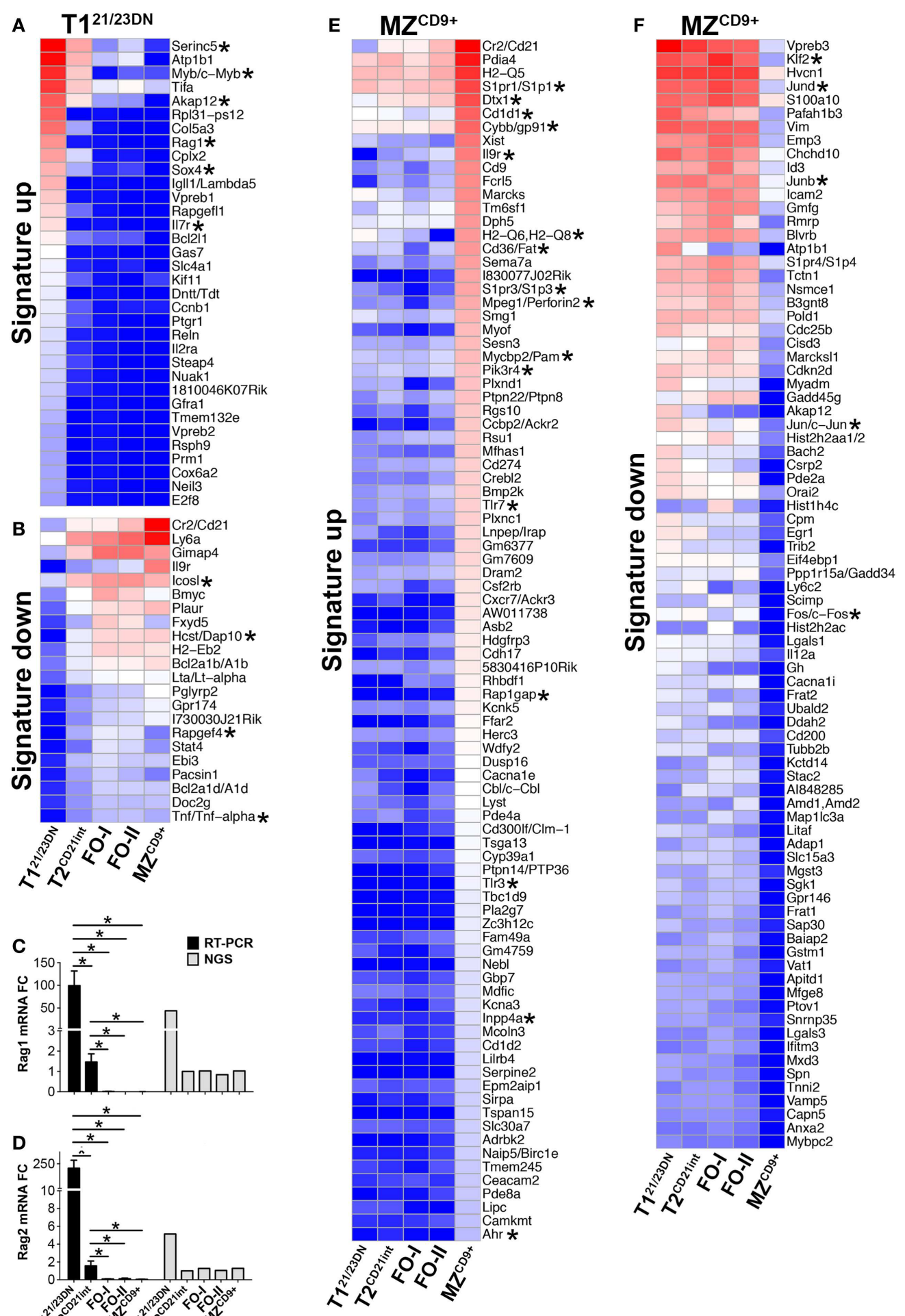

FIGURE $3 \mid T 1^{21 / 23 D N}$ and $M Z^{\mathrm{CD} 9+} \mathrm{B}$-cell subsets are highly enriched for signature genes. (A-D) RAG1 and RAG2 transcripts are prominent $T 1^{21 / 23 \mathrm{DN}}$ signature genes. Heatmap displaying $z$-scores of $T 1^{21 / 23 \mathrm{DN}}$ signature genes $(\mathrm{FC}>4)$ that are uniquely up-regulated $(\mathbf{A})$ or down-regulated (B). qRT-PCR analysis validated NGS results showing RAG1 and RAG2 are up-regulated T1 $1^{21 / 23 D N}$ signature genes. (C) RAG1 mRNA expression by qRT-PCR (black bars) and RNA-Seq (gray bars) and (D) RAG2 mRNA expression analyzed as in (C). qRT-PCR data represent three independent experiments with FACS-sorted B-cell subsets, where each experiment utilized pooled splenocytes from 2 to 5 mice ${ }^{*} p \leq 0.05$ $(\mathbf{E}, \mathbf{F}) \mathrm{MZ}^{\mathrm{CD} 9+} \mathrm{B}$-cells show highest number of signature genes. Heatmap displaying $z$-scores of $\mathrm{MZ}^{\mathrm{CD} 9+}(\mathrm{FC}>4)$ that are uniquely up-regulated $(\mathrm{E})$ or down-regulated (F). Asterisks in heatmaps denote genes discussed in the text. Due to the high number of up-regulated signature genes in $\mathrm{MZ}^{\mathrm{CD} 9+}$ cells, genes below Ahr (57 out of 146) were removed but can be referenced in Table S1 in Supplementary Material. 

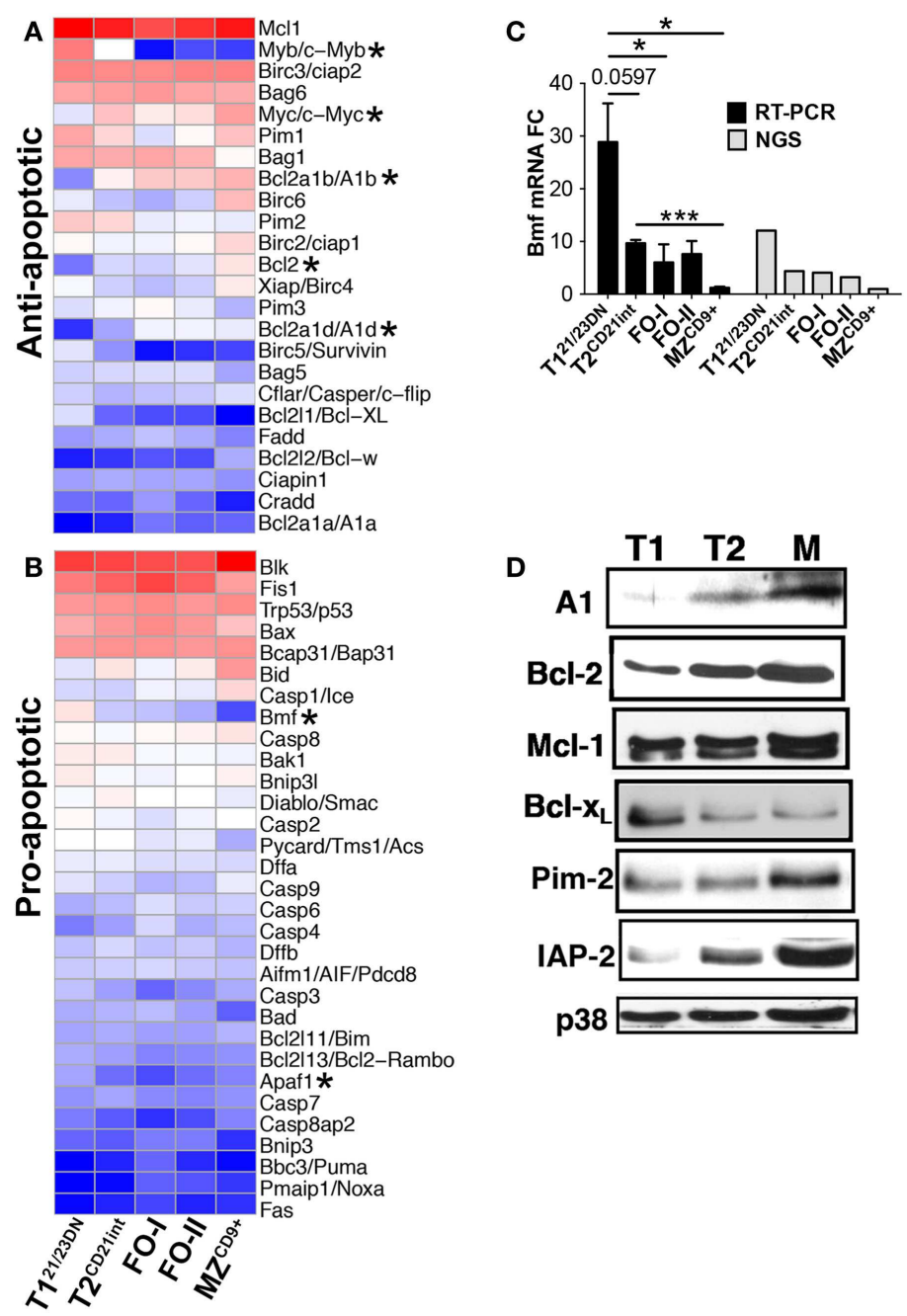

E

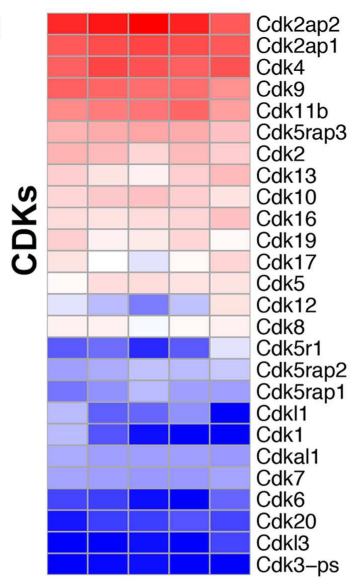

$\mathbf{F}$

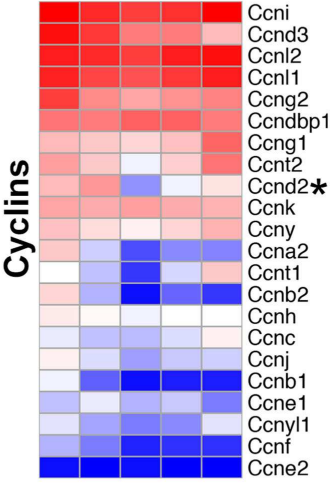

G

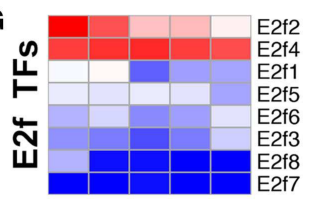

H

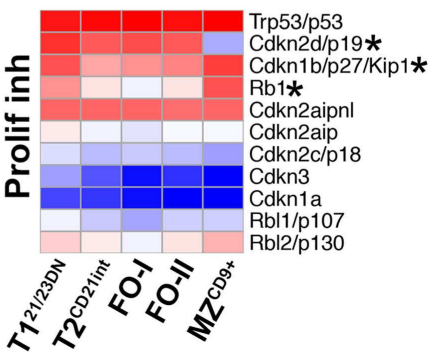

FIGURE 4 | Differentially expressed genes define apoptotic and proliferative potential of transitional and mature B-cell subsets. Heatmap display of NGS data analysis of genes encoding (A) antiapoptotic, (B) pro-apoptotic, (E) cyclin dependent kinases (CDKs), (F) cyclins, (G) E2F cell cycle transcription factors, and (H) proliferation inhibitors, using z-scored NGS gene expression data. Asterisks denote important genes discussed in the text. (C) qRT-PCR analysis (black bars) validated NGS results (gray bars) showing upregulation of Bmf in $T 1^{21 / 23 D N}$ cells. qRT-PCR data are representative of three independent experiments with FACS-sorted B-cell subsets, where each experiment utilized pooled splenocytes from 2 to 5 mice. ${ }^{*} P \leq 0.05$; ${ }^{*} P \leq 0.01$; ${ }^{* * *} P \leq 0.001$. (D) Western blot of anti-apoptotic proteins showing key survival factors such as $\mathrm{Bcl}-2$ increase during differentiation. p38 served as a loading control. stage-specific genes, we exploited 1581 TRs recently used to define transcriptional architecture of human hemato- and lymphopoiesis (26). A major shift in the expression of TRs accompanied $\mathrm{T} 1^{21 / 23 \mathrm{DN}}$ to $\mathrm{T} 2^{\mathrm{CD} 21 \text { int }}$ differentiation (Figure 2A). These included Myb, Sp3, and Sox4 at the $\mathrm{T}^{21 / 23 \mathrm{DN}}$ stage whereas Myc, Bmyc, Rar $\alpha$, Nr4a1/Nur77, and Cebpb were prominent at the T2 ${ }^{\mathrm{CD} 21 \text { int }}$ stage. These TRs are predicted to regulate key biological processes with Myc alone regulating over $19 \%$ of DE genes at the T2 ${ }^{\mathrm{CD} 21 \text { int }}$ stage (Tables S2 and S3 in Supplementary Material).

We also identified TFs relevant for transitional B-cell maturation, e.g., down-regulation of B-cell differentiation TF Gfil coincided with differentiation of transitional into mature B-cells 
A Myc associated

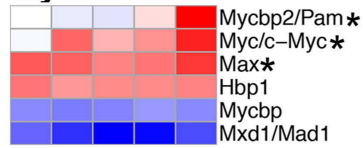

B Sphingosine receptors

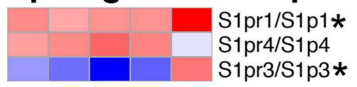

C Inositol kinase signal
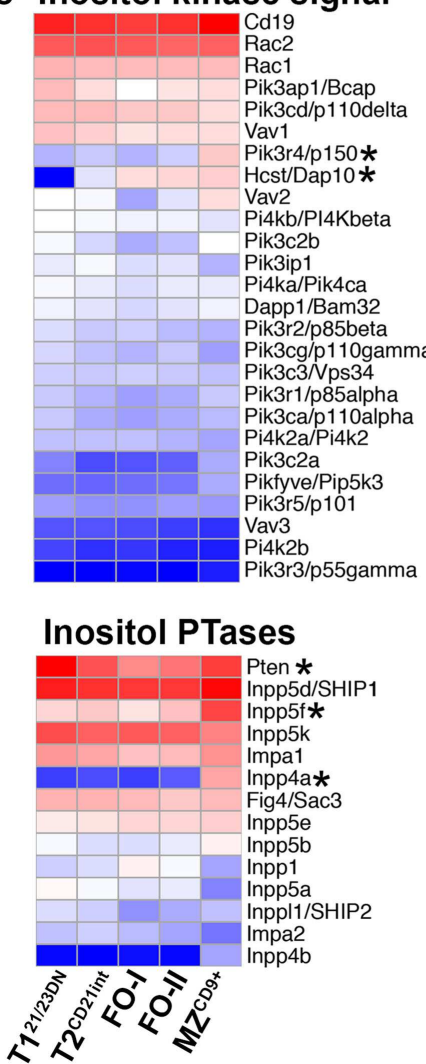

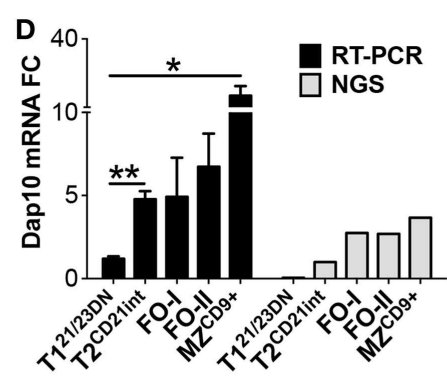

E Ras family

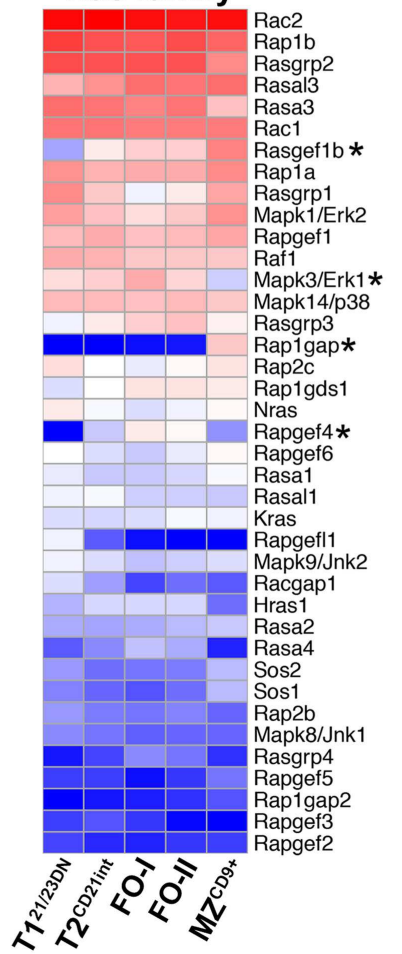

F Ser/Thr PTase

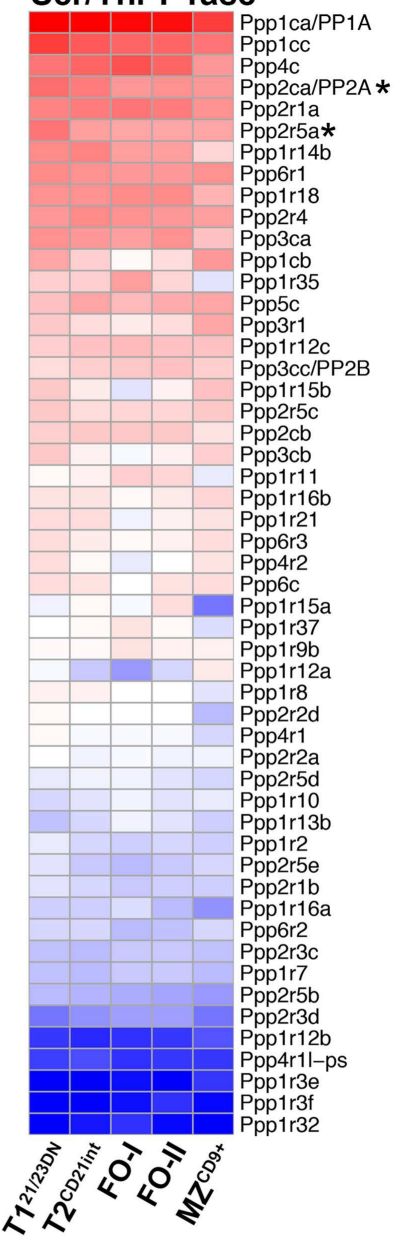

FIGURE 5 | Gene expression profiles predict PI3K/Ras signaling stabilizes Myc during B-cell development. Heatmap display of

(A) Myc associated genes including Myc binding partners Pam and Max, (B) sphingosine receptors possibly mediating Pam/mTOR signaling,

(C) inositol kinase signaling molecules including Dap10 (bottom) as well as inositol phosphatases (bottom), (E) Ras family genes, and
(F) Serine/threonine phosphatases. (D) qRT-PCR analysis (black bars) validated NGS results (gray bars) showing upregulation of Dap10 starting at the T2 $2^{\text {CD2lint }}$ stage. qRT-PCR data are representative of three independent experiments with FACS-sorted B-cell subsets, where each experiment utilized pooled splenocytes from 2 to 5 mice. ${ }^{*} P \leq 0.05$; ${ }^{*} P \leq 0.01$.
(Figure 2D) (27). Conversely, proliferation-promoting Pou6f1 was enriched over three-fold in mature B-cells (Figure 2B) (28). $\mathrm{T} 2^{\mathrm{CD} 21 \text { int }}$ to $\mathrm{FO}$ differentiation is regulated mainly by metalion binding TFs (Table S3 in Supplementary Material). Further, more TRs were up-regulated in FO-I relative to FO-II consistent with FO-II being less differentiated (Figure 2G). GeneGo analysis predicted Tbet, Rar, and Titf/Nkx2-1 TFs were required for differentiation into FO-I whereas Nfatc2 is likely to be essential for FO B-cell function (Table S2 in Supplementary Material). Zfp467 and Stat 4 were specifically enriched in FO-I and FO-II (Figure 2C) and may therefore selectively regulate FO differentiation and function.
Interestingly, Klf2 was predicted to drive FO-II $\rightarrow$ FO-I terminal differentiation suggesting expression of Klf2 may determine FO-II fate into either FO-I or MZ (Table S3 in Supplementary Material). These data reinforce a T2/FO B-cell differentiation cluster requiring relatively few $\mathrm{DE}$ TRs.

$\mathrm{T} 2{ }^{\mathrm{CD} 21 \text { int }}$ to $\mathrm{MZ}^{\mathrm{CD} 9+}$ differentiation required substantial and unique TR rewiring, particularly TFs with zinc-finger and PAS domains (Figure 2E; Table S3 in Supplementary Material). Many DE TRs involved in $\mathrm{T} 1^{21 / 23 \mathrm{DN}}, \mathrm{T} 2^{\mathrm{CD} 21 \text { int }}$, or FO-II differentiation into $\mathrm{MZ}^{\mathrm{CD} 9+}$ overlapped suggesting commonality in $\mathrm{MZ}^{\mathrm{CD} 9+}$ fate (Figure 2H). Signature $\mathrm{MZ}^{\mathrm{CD} 9+}$ TRs included those not 

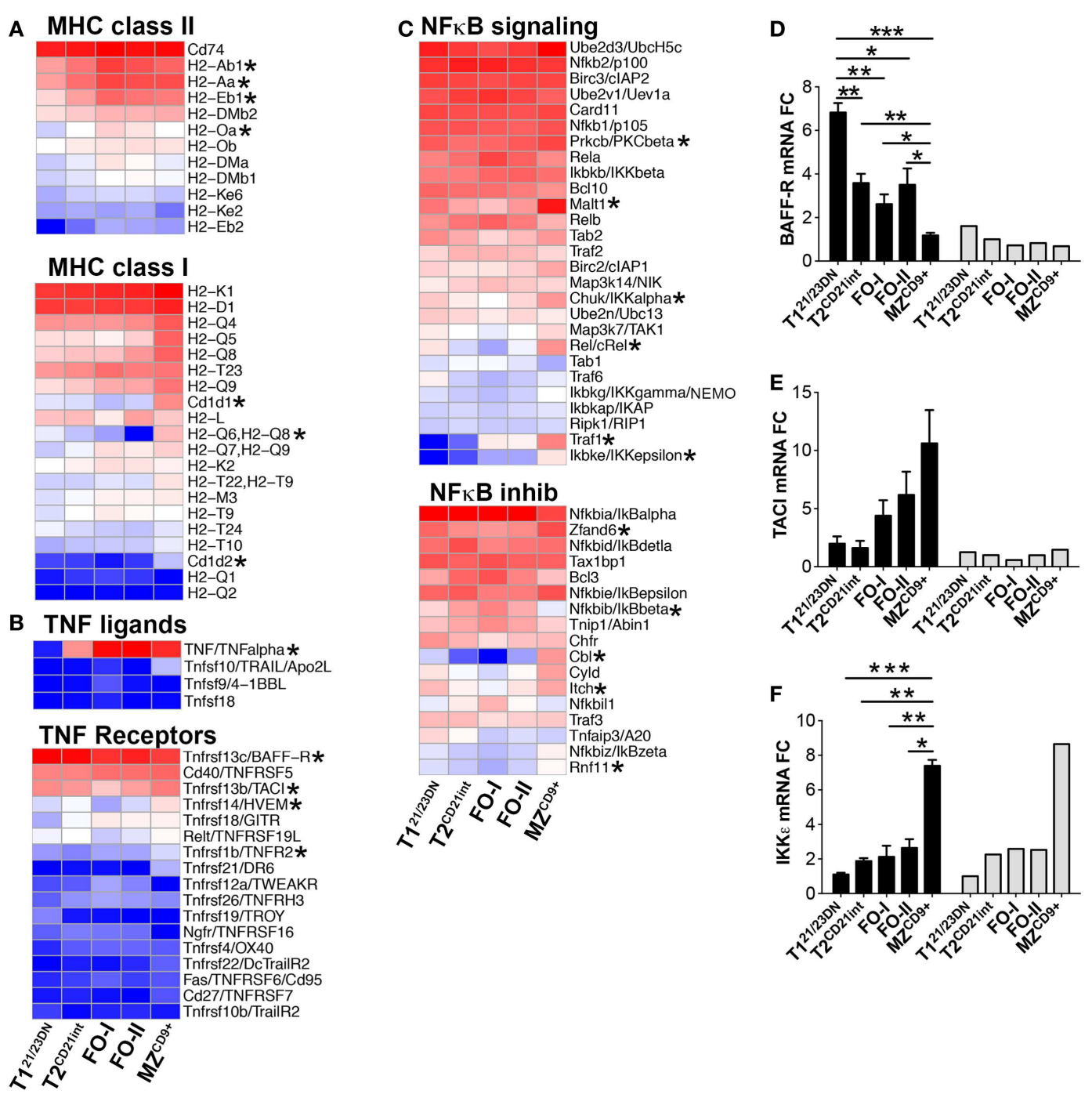

FIGURE $6 \mid(\mathbf{A}, \mathbf{B})$ Expression of genes associated with immune competence from the T2 $2^{\mathrm{CD} 21 \text { int }}$ stage and $(\mathbf{C}-\mathbf{F})$ upregulation of genes associated with activated and innate characteristics of $\mathrm{MZ}^{\mathrm{CD9} 9+}$ cells. Heatmap display of (A) MHC class II (top) and MHC class I (bottom), (B) TNF ligands (top) and TNF receptors (bottom), and (C) NFKB signaling components (top) and NFKB inhibitors (bottom). qRT-PCR analysis (black bars) validated NGS results (gray bars) of (D) BAFF-R, (E) TACl, and (F) IKKE. qRT-PCR data are representative of three independent experiments with FACS-sorted B-cell subsets, where each experiment utilized pooled splenocytes from 2 to 5 mice. ${ }^{*} P \leq 0.05$; ${ }^{*} P \leq 0.01$. previously linked to $\mathrm{MZ}^{\mathrm{CD} 9+}$ differentiation and function. One example is Myc binding protein 2 (PAM), which is expressed 4.5-fold higher in $\mathrm{MZ}^{\mathrm{CD} 9+}$ compared to other subsets. We also observed that many TFs [Jund, Junb, Jun, Fos, and Klf2 (29)] were uniquely down-regulated in $\mathrm{MZ}^{\mathrm{CD} 9+}$ (Figure 2D). TFs uniquely up-regulated in $\mathrm{MZ}^{\mathrm{CD} 9+}$ cells were predicted to regulate many genes, including those involved in innate immune response (Table S2 in Supplementary Material). Reduced HDAC and distinct HAT expression profile in $\mathrm{MZ}^{\mathrm{CD} 9+}$ cells was consistent with dramatically altered transcriptome (Figure 2F). Additionally, we observed Nfat TFs (Nfat5, Nfatc1) as well as Nfat activator Nfam1 were particularly enriched in $\mathrm{MZ}^{\mathrm{CD} 9+}$ cells (Table $\mathrm{S} 1$ in Supplementary Material). Thus, we have identified previously known and unknown TRs that contribute to $\mathrm{MZ}^{\mathrm{CD} 9+}$ differentiation and function.
TRANSCRIPTOME ASSOCIATED WITH PERIPHERAL B-CELL TOLERANCE To systematically define transcriptional programs that regulate alterations in fundamental processes/genes and eventual biological properties of individual B-cell subsets, we identified genes uniquely expressed or repressed termed signature genes (Figure 3; Table S1 in Supplementary Material). T1 ${ }^{21 / 23 D N}$ were enriched in mitosis factors including cyclins, microtubule motor activity, nucleoside binding, DNA biosynthesis and recombination, and serine/threonine kinases and were deficient in MHCII, B-cell mediated immunity, positive regulation of $\mathrm{NF} \kappa \mathrm{B}$, and cytokine and metabolic activity (Figures 3A,B; Table S3 in Supplementary Material). Given that DNA recombination is critical for receptor editing, we confirmed that $\mathrm{T} 1^{21 / 23 \mathrm{DN}}$ cells uniquely expressed RAG1 and RAG2 (Figures 3C,D). Although previous reports have shown differential RAG expression in splenic transitional B-cells, 

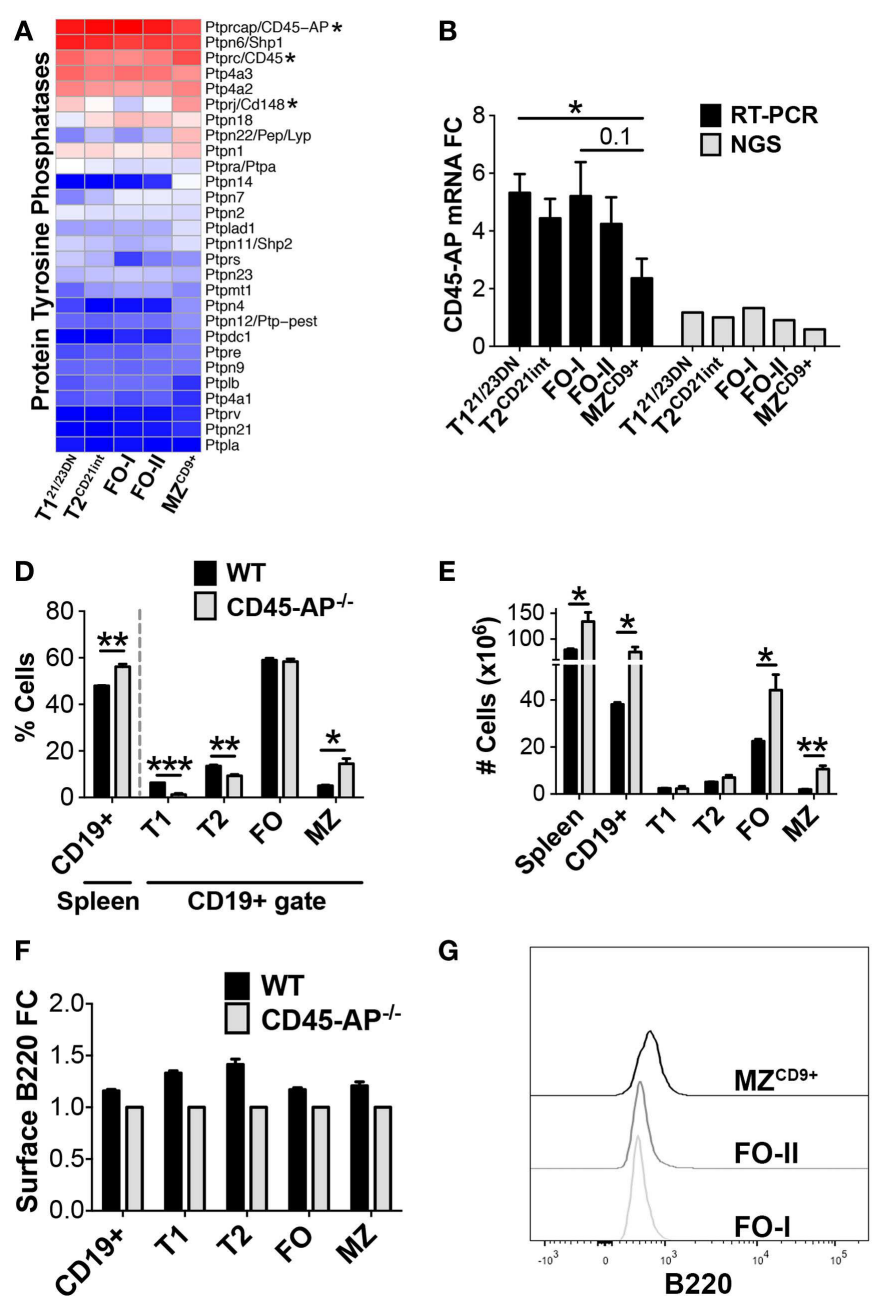
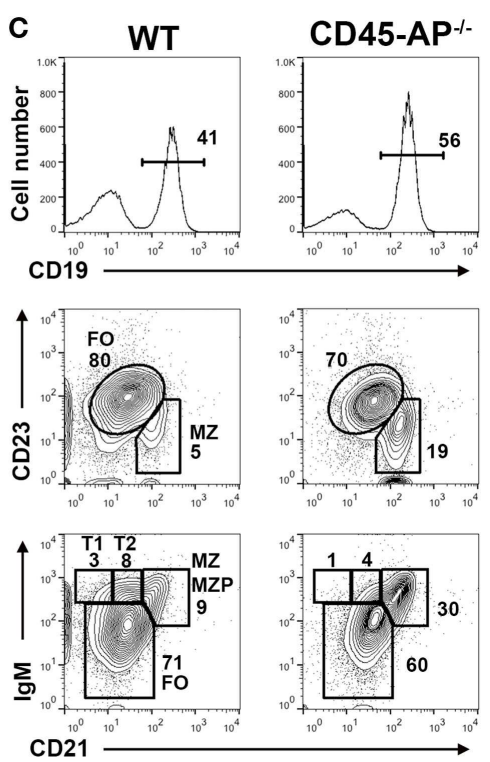

H

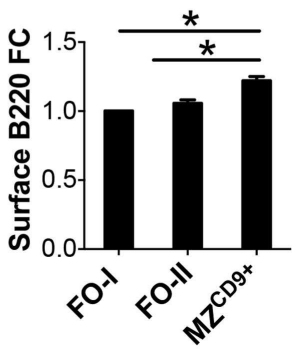

FIGURE 7 | CD45-AP limits premature entry of transitional B-cells into the mature B-cell pool. (A) Heatmap display of protein tyrosine phosphatases including tyrosine phosphatase PTPN22, CD45/Ptprc, and CD45 binding partner CD45-AP/Ptprc-ap (astericks). (B) qRT-PCR analysis validated NGS results showing CD45-AP is down-regulated in $M Z^{\mathrm{CD} 9+} \mathrm{B}$-cells. CD45-AP mRNA expression by qRT-PCR (black bars) and RNA-Seq (gray bars). qRT-PCR data are representative of three independent experiments with FACS-sorted B-cell subsets, where each experiment utilized pooled splenocytes from 2 to 5 mice. (C) Phenotypic analysis of splenic B-cells isolated from WT and CD45-AP ${ }^{-1-}$ mice. Histogram showing percent of CD19+ B-cells within splenocytes (top panels). CD19+ gated B-cells were further analyzed for transitional (T1 and T2), FO, and MZ B-cells. CD23 versus CD21 staining is used to differentiate $\mathrm{MZ}\left(\mathrm{CD} 21^{\mathrm{hi}}, \mathrm{CD} 23^{\mathrm{lo}}\right)$ and FO (CD21 $\left.1^{\text {lo-int }}, \mathrm{CD} 23^{+}\right) . \lg \mathrm{M}$ versus CD21 allows for analysis of additional subsets such as T1 (lgM ${ }^{\text {hi }}$, $\left.\mathrm{CD}_{21}{ }^{-}\right), \mathrm{T} 2\left(\operatorname{lgM}^{\mathrm{hi}}, \mathrm{CD} 21^{\text {lo-int }}\right)$, and preMZ (MZP). Data are representative of three mice. Bar graph representation of B-cell subset percentages (D) and numbers from three mice (E). (F) Absence of CD45-AP modestly affects cell-surface display of B220 protein. FCM analysis of WT versus CD45-AP ${ }^{-1-}$ splenic B-cell subsets for the expression of B220. (G) $\mathrm{MZ}^{\mathrm{CD} 9+}$ have the highest surface expression of B220. Post-sort surface B220 expression of sorted FO-I, FO-II, and MZ ${ }^{\mathrm{CD} 9+}$ B-cells (refer to Figure S1 in Supplementary Material) and plotted in (H) bar graph. ${ }^{*} P \leq 0.05 ;{ }^{*} P \leq 0.01 ;{ }^{*}{ }^{*} P \leq 0.001$. we observed much greater FC possibly because our sorting scheme excluded $\mathrm{CD} 21^{+}$and $\mathrm{CD} 23^{+}$cells (30).

Apoptosis and cell cycle control are integral to transitional Bcell tolerance and maturation. Unexpectedly, we did not observe a generalized enrichment of apoptosis and/or cell cycle regulatory genes in any $\mathrm{B}$-cell subset. However, $\mathrm{T} 1^{21 / 23 \mathrm{DN}}$ subset was enriched in select pro-apoptotic genes (Bmf and Apaf1) suggesting their role in negative selection (Figures $4 \mathrm{~A}-\mathrm{C}$ ). As expected, apoptosis-resistant $\mathrm{T} 2^{\mathrm{CD} 21 \text { int }}$ cells were enriched for anti-apoptotic genes Bcl-2alb/d and Bcl-2. Bcl-2 and other antiapoptotic protein levels largely corresponded with the gene expression (Figure 4D). $\mathrm{T} 1^{21 / 23 \mathrm{DN}}$ cells also expressed higher cell cycle repressors $\mathrm{Rb} 1$ and $\mathrm{Cdkn} 1 \mathrm{~b}$ whereas $\mathrm{T} 22^{\mathrm{CD} 21 \text { int }}$ cells expressed slightly higher Myc-target gene cyclin Ccnd2, a key regulator of proliferation (31) (Figures $4 \mathbf{E}-\mathbf{H}$ ). These findings are consistent with $\mathrm{T} 1^{21 / 23 \mathrm{DN}}$ sensitivity to apoptosis and tolerance checkpoint.

\section{TRANSCRIPTOME ASSOCIATED WITH B-CELL MATURATION AND IMMUNE COMPETENCE}

Myc is kept in check in $\mathrm{T} 1^{21 / 23 \mathrm{DN}}$ and up-regulated in $\mathrm{T} 2^{\mathrm{CD} 21 \text { int }}$ and beyond (Figure 5A). Due to their significance in stabilizing Myc, we focused on PI3K and Ras signaling $(32,33)$. We found $T 1^{21 / 23 D N}$ cells were significantly deficient for PI3K 

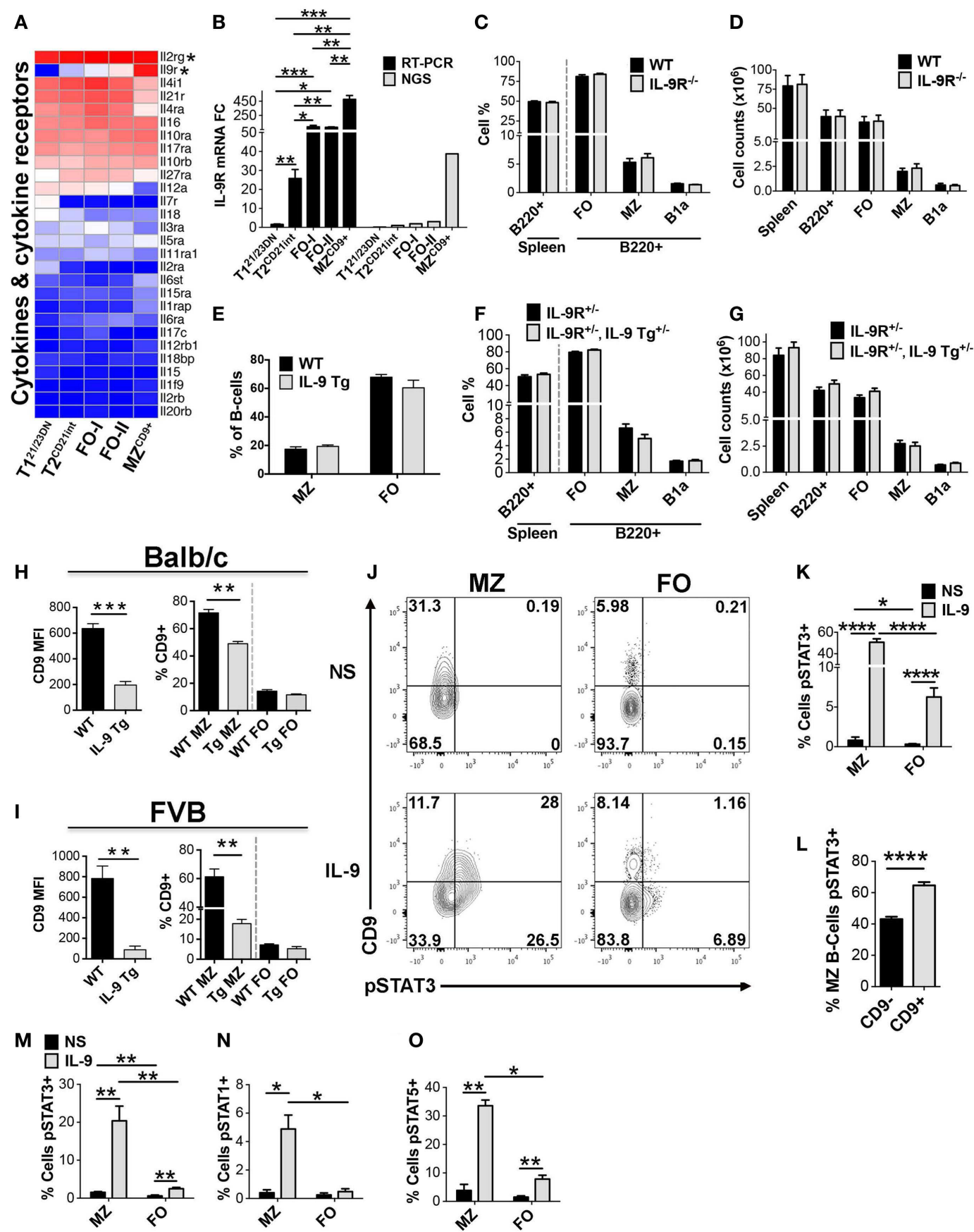

\section{FIGURE 8 | Increased IL-9R expression manifests in enhanced} responsiveness of $\mathbf{M Z} \mathbf{Z}^{\mathbf{C D} 9+} \mathbf{B}$-cells to IL-9. Increased IL-9R expression manifests in enhanced responsiveness of $M Z^{\mathrm{CD} 9+}$ B-cells to IL-9. (A) Heatmap display of cytokine and cytokine receptors including IL-9R and its heterodimerization partner IL-2Rg (astericks). (B) qRT-PCR analysis validated NGS results showing IL-9R is a $\mathrm{MZ}^{\mathrm{CD} 9+}$ up-regulated signature gene. IL-9R mRNA expression by qRT-PCR (black bars) and RNA-Seq (gray bars). qRT-PCR data are representative of three independent experiments with FACS-sorted B-cell subsets, where each experiment utilized pooled splenocytes from 2 to 5 mice. (C-D) IL-9R is dispensable for splenic B-cell development. Bar graph displaying $\mathrm{MZ}\left(\mathrm{B} 220^{+}, \mathrm{CD} 21^{\mathrm{hi}}, \mathrm{CD} 23^{\mathrm{lo}}, \lg ^{\mathrm{hi}}\right)$ and $\mathrm{FO}\left(\mathrm{B} 220^{+}, \mathrm{CD} 21^{\text {lo-int }}\right.$, $\mathrm{CD}_{23} 3^{\text {hi }}, \operatorname{lgM}^{+}$) B-cell subset percentages (C) and numbers (D) from Balb/c control versus IL-9R ${ }^{-l-}$ mice. FO represents follicular B-cell populations (FO-I,
FO-II, and T2 B-cells). B1a B-cells were gated as (B220+, CD23-, IgM hi, $\left.\mathrm{CD}^{+}\right)$. Data are representative of six mice. Transgenic over-expression of IL-9 does not affect B-cell development. (E) Bar graph displaying $\mathrm{MZ}\left(\mathrm{B} 220^{+}, \mathrm{CD} 21^{\mathrm{hi}}\right.$, $\left.\mathrm{CD}_{2} 3^{\mathrm{lo}}, \operatorname{lgM}^{\mathrm{hi}}\right)$ and $\mathrm{FO}\left(\mathrm{B} 220^{+}, \mathrm{CD} 21^{\text {lo-int }}, \mathrm{CD} 23^{\mathrm{hi}}, \operatorname{lgM}^{+}\right)$B-cell percentages from FVB WT control and IL-9 transgenic (Tg5) mice. Data are representative of three mice. (F,G) Bar graph displaying MZ (B220+, CD21 hi, CD23 $\left.{ }^{\text {lo }}, \operatorname{lgM}^{\text {hi }}\right)$ and FO $\left(B 220^{+}, C D 21^{\text {lo-int }}, \mathrm{CD}_{2} 3^{\mathrm{hi}}, \operatorname{lgM}^{+}\right)$B-cell subset percentages (F) and numbers (G) from Balb/c IL-9R $\mathrm{R}^{+/-}$control mice and IL-9 transgenic (Tg5) heterozygotes (IL-9R $\mathrm{R}^{+/-}$, IL-9 $\mathrm{Tg}^{+/-}$) mice. Data are representative of six mice. $(\mathbf{H}, \mathbf{I}) \mathrm{MZ}$ B-cells display reduced cell-surface CD9 in transgenic mice overexpressing IL-9. Left bar graphs show CD9 mean fluorescence intensity (MFI) of MZ B-cells $\left(B 220^{+}, \mathrm{CD} 21^{\text {hi }}, \mathrm{CD} 23^{\text {lo }}\right)$

(Continued) 


\section{FIGURE 8 | Continued}

comparing WT versus IL-9 Tg mice. Right bar graphs show the percentage of cells displaying $\mathrm{CD}^{+}$positivity comparing $\mathrm{MZ}$ versus $\mathrm{FO}$ B-cells $\left(\mathrm{B} 220^{+}, \mathrm{CD} 21^{\text {lo-int }}, \mathrm{CD}^{2} 3^{+}\right)$. Bar graphs in $\mathrm{H}$ and $\mathrm{I}$ are representative of three mice. (J,K) Short term IL-9 induces STAT3 activation selectively in MZ B-cells. (J) FCM analysis of pSTAT3 in FVB splenic MZ (B220 ${ }^{+}, C D 21^{\text {hi }}$, $\mathrm{CD} 23^{\text {lo) }}$ versus $\mathrm{FO}\left(\mathrm{B} 220^{+}, \mathrm{CD} 21^{\text {loint }}, \mathrm{CD} 23^{+}\right)$B-cells stimulated or non-stimulated (NS) with bacculo-produced IL-9 $(3.5 \mathrm{ng} / \mathrm{mL})$ for $15 \mathrm{~min}$ at $37^{\circ} \mathrm{C}$. FO represents follicular B-cell populations (FO-I, FO-II, and T2
B-cells). Numbers in quadrants represent the percentage of cells. (K) Bar graph comparing the percentage of pSTAT3 positive cells in MZ versus FO B-cells. (L) Bar graph comparing the percentage of pSTAT3 positive cells in $\mathrm{CD9}^{+}$versus $\mathrm{CD9}^{-} \mathrm{MZ} \mathrm{B}$-cells. Data from $(\mathbf{H}-\mathbf{J})$ are representative of five mice. (M-O) IL-9 induction of pSTAT3 is independent of genetic background. Balb/c wild-type mice were treated as in $\mathrm{J}$ and stained for either pSTAT3, pSTAT1, or pSTAT5. pSTAT3 data (M) represent three mice whereas PSTAT1 $(\mathbf{N})$ and PSTAT5 $(\mathbf{O})$ data represent two mice. ${ }^{*} P \leq 0.05$; ${ }^{*} P \leq 0.01 ;{ }^{* *} P \leq 0.001 ; *{ }^{*}{ }^{*} P \leq 0.0001$.

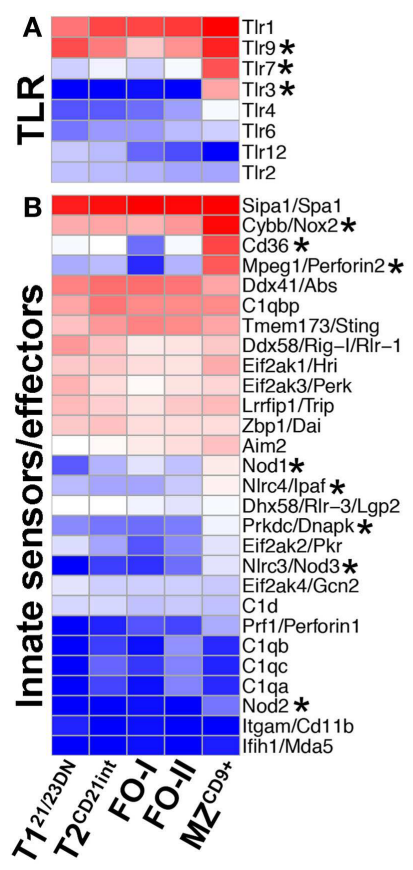

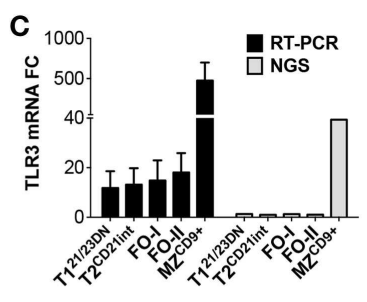

D

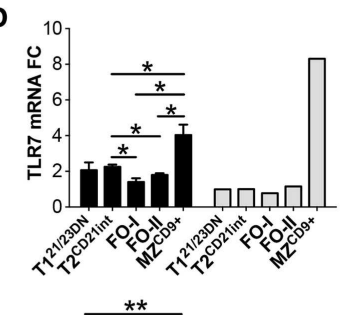

E

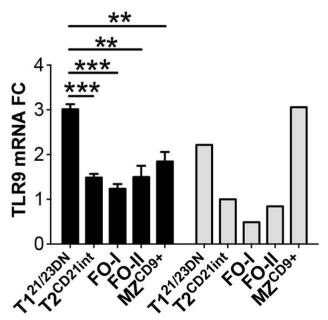

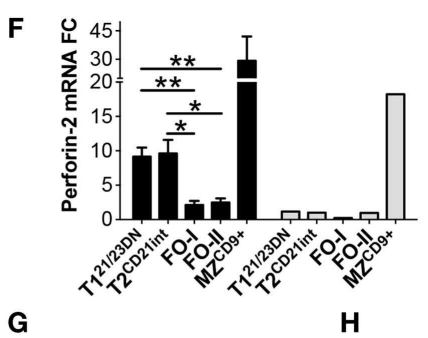

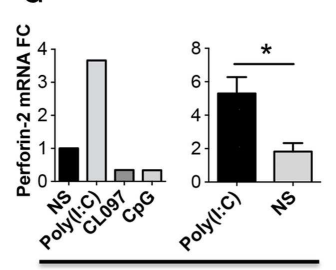

Total B-cells

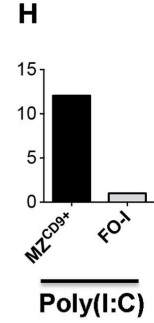

FIGURE 9 | $\mathrm{MZ}^{\mathrm{CD9}}+\mathrm{B}$-cell subset is poised for innate immune responses. Heatmap display of NGS data showing enrichment of (A)TLR and (D) innate immune sensors/effector genes. Asterisks denote important genes discussed in the text. qRT-PCR analysis validated NGS results showing $\mathrm{MZ}^{\mathrm{CD} 9+}$ express highest amounts of TLR3, TLR7 and Perforin-2. qRT-PCR (black bars) and RNA-Seq (gray bars) of (B) TLR3, (C) TLR7, and (E) Perforin-2. qRT-PCR data are representative of three independent experiments with FACS-sorted B-cell subsets, where each experiment utilized pooled splenocytes from 2 to 5 mice. (F) qRT-PCR of
Perforin-2 mRNA fold-change after stimulation with endosomal TLR agonists. B220 positively selected cells (>95\% purity) were stimulated $18 \mathrm{~h}$ with either TLR3 agonist Poly(I:C), TLR7/8 agonist CL097, or TLR9 agonist $\mathrm{CpG}$ at $1 \mu \mathrm{g} / \mathrm{mL}$ and compared to NS. (G) qRT-PCR of Perforin-2 mRNA fold-change using B220 positive (>95\% purity) or CD43 negative ( $90 \%$ purity) B-cells stimulated with Poly(l:C) as in (F). Data are representative of four independent experiments. (H) qRT-PCR of Perforin-2 mRNA fold-change using FACS derived $\mathrm{MZ}^{\mathrm{CD} 9+}$ or FO-I B-cells treated with Poly(l:C) as in (F). ${ }^{*} P \leq 0.05 ;{ }^{*} P \leq 0.01$. adaptor protein HCST (DAP10) as well as Ras signaling molecules RasGef1b and RafGef4 (Epac2) (Figures 5C-E). Instead, T1 $1^{21 / 23 D N}$ cells expressed twofold more PI3K antagonist PTEN (34) and highest catalytic and regulatory subunits of Protein phosphatase 2A (PP2A/Ppp2ca, B56alpha/Ppp2r5a) to increase Myc degradation (Figures 5C,F) (35). Stunted Myc expression in $\mathrm{T} 1^{21 / 23 \mathrm{DN}}$ cells likely prevents autoreactive B-cell survival and maturation. Differentiation past $\mathrm{T} 1^{21 / 23 \mathrm{DN}}$ stage coincided with a significant upregulation of $\mathrm{MHCII}$ genes (H2-Ab1/Aa/Eb1/Oa), a hallmark of immune competence (Figure 6A; Table S3 in Supplementary Material). Consistently, T2 ${ }^{\mathrm{CD} 21 \text { int }}$ were also enriched for Fcer1g, CR2/CD21, complement factors, Icosl and TNF $\alpha$ (Figure 6B; Table S3 in Supplementary Material).
In contrast to $\mathrm{T} 1^{21 / 23 \mathrm{DN}}, \mathrm{Ppp} 2 \mathrm{ca}$ and Ppp2r5a were lowest in $\mathrm{MZ}^{\mathrm{CD} 9+}$, inversely correlating with the Myc levels (Figure 5F). Enhanced Myc along with a distinct transcriptome, including many signature genes, contribute to the activated state of $\mathrm{MZ}^{\mathrm{CD} 9+}$ cells (Table S1 and S3 in Supplementary Material). Consistent with this state, $\mathrm{MZ}^{\mathrm{CD} 9+}$ were enriched for genes that positively regulate $\mathrm{NF \kappa B}$ signaling (Rel, Traf1, Ik $\beta \mathrm{k} \varepsilon$, Ikk $\alpha$, Malt1, PKC $\beta$ ). Additionally, negative NFKB regulator $(\mathrm{I} \kappa \mathrm{B} \beta$ ) as well as proliferation inhibitor Cdkn2d were exclusively down-regulated (31, 36) (Figures 6C,F). However, to prevent overactivity of Myc, $\mathrm{MZ}^{\mathrm{CD} 9+} \mathrm{B}$-cells also have heightened expression of negative regulators Inpp5f, Inpp4a, PTEN, Rap1gap, down-regulated Mapk3, and increased expression of NFKB negative regulators Zfand6, Itch, 
Rnf11, and most notably Cbl (Figures 5C,E and 6C) (31, 37-39). Overall, these data suggest $\mathrm{MZ}^{\mathrm{CD} 9+}$ cells are primed for quick immune responses including TACI-dependent T-independent immune response (Figure 6E) (40). Finally, $\mathrm{MZ}^{\mathrm{CD} 9+}$ cells were also enriched for MHCI molecules, especially H2-Q6 suggesting $\mathrm{MZ}^{\mathrm{CD} 9+}$ cells are more suited to present certain types of antigens consistent with their known ability to present glycolipid antigens via CD1d (Figure 6A) (13). Interestingly, transcriptome analysis comparing follicular subsets showed FO-I were enriched in histone gene expression while FO-II were enriched for genes involved in lymphocyte and complement activation as well as RNA binding (Figure S1J in Supplementary Material; Table S3 in Supplementary Material). This indicates FO-II share some innate-like qualities with $\mathrm{MZ}^{\mathrm{CD} 9+}$ cells, albeit not as robustly (e.g., CD36 and Perforin2, Figure 9B), and that they are likely capable of context-dependent plasticity (11).

\section{CD45-AP REGULATES MZ B-CELL HOMEOSTASIS}

Bioinformatic analysis indicated enhanced regulation of kinase activity in $\mathrm{MZ}^{\mathrm{CD} 9+}$ cells (Table S3 in Supplementary Material). For example, PTPN22 tyrosine phosphatase, a negative regulator of BCR signaling, is expressed highest in $\mathrm{MZ}^{\mathrm{CD} 9+}$ relative to the B-cell subsets analyzed (Figure 7A). Of note, polymorphisms in PTPN22 that render B-cells (and T and innate cells) hyperresponsive and are associated with many autoimmune diseases $(41,42)$. Conversely, CD45 phosphatase is a major positive regulator of BCR-induced kinase activity (15). Kinase activity is critical for BCR signaling strength, which has been proposed to regulate $\mathrm{MZ}$ versus FO-cell fate (11). Our NGS and qRT-PCR data revealed that CD45-associated protein (CD45-AP/Ptprc-ap) was 2.5-fold reduced in $\mathrm{MZ}^{\mathrm{CD} 9+}$ relative to FO-I cells (Figures 7A,B). CD45-AP is one of the most abundantly expressed genes (FOI FPKM = 1500). Up to $75 \%$ of CD45-AP protein complexes with and potentially positively regulates phosphatase activity of CD45, a key positive regulator of BCR signaling (15). However, the role of CD45-AP in B-cell development and homeostasis remains unknown. Therefore, we analyzed splenic B-cell development in mice deficient for CD45-AP (CD45-AP ${ }^{-/-}$) (15). FCM analysis of $\mathrm{CD} 45-\mathrm{AP}^{-/-}$mice revealed reduced percentage of transitional B-cells ( $\mathrm{T} 1$ and $\mathrm{T} 2$ ) despite an overall increase in B-cell numbers (Figures 7C-E). Although absolute numbers of FO Bcells were increased, their proportion did not. In contrast, both proportions and absolute numbers of MZ B-cells were significantly increased (Figures 7C-E). Additionally, absence of CD45AP slightly reduced cell-surface B220 (CD45) potentially further reducing BCR signaling strength (Figure 7F). These results suggest that altered signaling by loss of CD45-AP either facilitates transitional B-cell maturation or survival and/or proliferation of mature B-cell subsets.

\section{SELECTIVE EXPRESSION AND FUNCTION OF IL-9R IN MZ B-CELLS}

IL-9R is uniquely enriched in $\mathrm{MZ}^{\mathrm{CD} 9+}$ cells (Figures $\mathbf{8 A}, \mathbf{B}$ ), even when compared to other immune cell populations (43). IL-9R interaction with IL-9 regulates inflammation, humoral immunity, and B1 B-cell expansion (17, 44-48). However, IL-9R function in MZ B-cells remains unknown. Therefore, we tested a role for IL$9 \mathrm{R}$ in MZ B-cell development and homeostasis using mice with
IL-9R gene deletion and transgenic mice over expressing IL-9. Distribution and numbers of splenic B-cell subsets in IL-9R deficient mice were comparable to controls, precluding a role for IL-9R in splenic B-cell development or homeostasis (Figures 8C,D). Likewise, IL-9 transgenic ( $\mathrm{Tg}$ ) mice did not show any significant alterations in splenic B-cell populations in two different genetic backgrounds, FVB and Balb/c (Figures 8E-G) $(17,48)$. However, a curious finding was that in IL-9 Tg mice MZ B-cells down-regulated cell-surface expression of CD9 in both genetic backgrounds compared to wild-type control mice (Figures $\mathbf{8 H}, \mathbf{I}$ ). These data are consistent with the highest level of IL-9R expression in MZ B-cells, as predicted by our RNA-Seq and RT-PCR data. Taken together, these results demonstrate that IL-9 and IL-9R are dispensable for B-cell development and homeostasis.

Down-regulation of cell-surface CD9 in MZ B-cells by overexpression of IL-9 suggested that IL-9/IL-9R signaling might be consequential in MZ B-cells. Therefore, we sought to experimentally test whether IL-9R in $\mathrm{MZ}^{\mathrm{CD} 9+} \mathrm{B}$-cells transmits intracellular signals. We measured Stat3 phosphorylation by FCM following IL-9 treatment. Compared to non-stimulated cells, low-dose IL-9 induced robust Stat3 phosphorylation primarily in MZ B-cells (Figures 8J,K). A much smaller increase was also observed in FO B-cells. Activation of pSTAT3 within MZ B-cells was higher in the $\mathrm{CD}^{+}{ }^{+}$than $\mathrm{CD}^{-}$fraction (Figure 8L). From preferential $\mathrm{MZ}^{\mathrm{CD} 9+} \mathrm{B}$-cell response to IL-9, it seems that this cell population may express highest cell-surface IL-9R protein, consistent with highest IL-9R transcript levels (NGS). Additional experiments showed that in addition to Stat3, IL-9 induced phosphorylation of Stat 1 and Stat5 in MZ B-cells. Since, these experiments were carried out with B-cells isolated from Balb/c mice, the results also demonstrate that selective responsiveness of $\mathrm{MZ} \mathrm{B}$-cells to IL-9 is independent of the genetic background (Figures $\mathbf{8 M - O}$ ). To our knowledge this is the first report to demonstrate IL-9/IL9R signaling in MZ B-cells. However, additional experiments are needed to determine the effects of this signaling on $\mathrm{MZ} B$-cell function.

\section{$\mathrm{MZ}^{\mathrm{CD}+}$ CELLS SELECTIVELY EXPRESS GENES ASSOCIATED WITH INNATE IMMUNITY}

Although MZ B-cells have been proposed to have innate-like properties, a comprehensive transcriptome analysis of these characteristics has not been performed $(13,49)$. Our analysis of innate immune sensors revealed that $\mathrm{MZ}^{\mathrm{CD} 9+}$ cells are enriched in the RNA sensing molecules Tlr3, Tlr7, and Nlrc3/Nod3, the bacterial peptidoglycan sensors Nod1/2/3 and Nlrc4 and the DNA sensors Tlr9 and Prkdc (Figures 9A-E) (50). Innate effector molecules such as respiratory burst oxidase gene Cybb, autophagy associated gene Pik3r4/p150, and the recently identified intracellular bactericidal Perforin-2 are also highly enriched in $\mathrm{MZ}^{\mathrm{CD} 9+}$ cells (Figure 5C and Figures 9B,F) $(51,52) . \mathrm{MZ}^{\mathrm{CD} 9+}$ cells are also enriched for IKKE, which provides a critical link to innate immune pathways under NFKB control. To our knowledge, this is the first report to suggest a biased use of this innate pathway in $\mathrm{MZ}^{\mathrm{CD} 9+}$ B-cells (Figures 6C,F) (53).

We chose TLR3 for functional assessment because it is exclusively expressed in $\mathrm{MZ}^{\mathrm{CD} 9+}$ cells. We show that in total $\mathrm{B}$ cells TLR3 agonist Poly(I:C) was unique among endosomal TLR 
agonists by inducing a threefold increase in Perforin-2/MPEG1 transcript (Figure 9G). Using sorted cells we showed that $\mathrm{MZ}^{\mathrm{CD} 9+}$, but not FO-I cells, exclusively induced Perforin-2 (Figure 9H). These results show that $\mathrm{MZ}^{\mathrm{CD} 9+}$ cells uniquely and functionally express TLR3, which can endow bactericidal function to $\mathrm{MZ}^{\mathrm{CD} 9+}$ B-cells through Perforin-2 induction.

\section{DISCUSSION}

This study is the first to report the mRNA transcriptome obtained by RNA-Seq of mouse splenic B-cell subsets $(43,54-58)$. Our data support the hypothesis that $\mathrm{MZ}^{\mathrm{CD} 9+}$ subset may arise from multiple precursors. Differentiation from $T 1^{21 / 23 \mathrm{DN}}$ would theoretically bypass CD23 expression (59). Further support for $\mathrm{T} 1^{21 / 23 \mathrm{DN}}$ to $\mathrm{MZ}^{\mathrm{CD} 9+}$ pathway comes from shared deficiency of $\mathrm{N}$-regions and an increase in TLR9 and Aiolos expression, both of which promote MZ differentiation (60-62). While FO-II could differentiate into MZ, they are most closely related to FO-I. PCA analysis additionally supported FO-II to be an intermediate of FO-I subset, possibly mediated by Klf2.

Enhanced expression of pro-apoptotic gene ( $\mathrm{Bmf})$ in $\mathrm{T} 1^{21 / 23 \mathrm{DN}}$ relative to $\mathrm{T} 2{ }^{\mathrm{CD} 21 \text { int }}$ supports the notion that autoreactive $\mathrm{B}$ cell are deleted by mitochondrial pathway of apoptosis at the T1-checkpoint (63). Our novel finding that Serine incorporator (Serinc5) is exclusively expressed in $\mathrm{T} 1^{21 / 23 \mathrm{DN}}$ cells may provide an additional mechanism of cell death by altering membrane composition and BCR signaling (64) (Figure 3A). Furthermore, we found expression of genes associated with DNA recombination (RAG1, RAG2, Ligase 4) exclusively in $\mathrm{T} 1^{21 / 23 \mathrm{DN}}$ cells suggesting receptor revision. These data suggest apoptosis and receptor revision contribute to peripheral tolerance at the T1-checkpoint.

We also found that up-regulated $\mathrm{T} 1^{21 / 23 \mathrm{DN}}$ signature gene Akap12 may uphold the $\mathrm{T} 1^{21 / 23 \mathrm{DN}}$ stage by interfering with activation, migration, and proliferation (Figure 3A) (65). Consistently, it is dramatically down-regulated in proliferative $\mathrm{T} 2{ }^{\mathrm{CD} 21 \text { int }}$ cells. To our knowledge, this is the first report to identify down-regulation of Akap12 as an indicator of proliferation in splenic B-cells.

Myb to Myc switch from $\mathrm{T} 1^{21 / 23 \mathrm{DN}}$ to $\mathrm{T} 2^{\mathrm{CD} 21 \text { int }}$ was highly consequential as these TFs regulated a substantial proportion of DE genes. We predict Rar $\alpha$ expression contributes to Myb downregulation (66). Onset of Myc expression in T2 ${ }^{\mathrm{CD} 21 \text { int }}$ cells profoundly influenced gene expression comprising one-fifth of all DE genes (67) conferring metabolic fitness and likely driving survival, proliferation and differentiation of $\mathrm{T} 2{ }^{\mathrm{CD} 21 \text { int }}$ into mature B-cells $(4,31,68,69)$. Consistently, our data show that $\mathrm{MZ}^{\mathrm{CD} 9+}$ expressed highest levels of Myc as well as Myc binding/regulatory proteins PAM and Max (Figure 5A). Consistent with their resting state, FOI cells express the least Myc of mature subsets, but express highest Bmyc, which we suggest transcriptionally represses Myc (70). Both heightened expression of Bmyc in FO-I and its potential function in B-cells have not been previously reported.

Our data also suggest uncoupling of the BCR from growth, metabolic, and Myc pathways (PI3K and Ras/ERK) contribute to the distinct $\mathrm{T} 1^{21 / 23 \mathrm{DN}}$ cell biology. This may be explained by our novel finding that the PI3K pathway may be may not be fully activated in $\mathrm{T} 1^{21 / 23 \mathrm{DN}}$ cells due to severely reduced levels of the Dap10 adapter for PI3K (71). This genetic data are supported by experimental evidence showing T1 cells only weakly activate the PI3K pathway (via Akt phosphorylation) $(3,5)$. Additionally, increased expression of negative regulators of BCR signaling PTEN, CD72, and PP2A would further limit the PI3K/Myc pathway in $\mathrm{T} 1^{21 / 23 \mathrm{DN}}$ cells $(34,35,72)$. Differentiation into T2 $2^{\mathrm{CD} 21 \text { int }}$ is also accompanied by Bcl-2 transcript and protein. Heightened expression of both Myc and Bcl-2 is a highly potent combination (highest in $\mathrm{MZ}^{\mathrm{CD} 9+}$ ) promoting survival during Myc-driven proliferation and frequently occurs in various B-cell lymphomas $(73,74)$. We suggest that survival at the $\mathrm{T} 2{ }^{\mathrm{CD} 21 i n t}$ stage is also supported by $\mathrm{TNF} \alpha$ as $\mathrm{T} 2{ }^{\mathrm{CD} 21 \text { int }}$ and mature B-cells express only pro-survival TNFR2 (75). Together, these data point to a previously unknown $\mathrm{PI} 3 \mathrm{~K}$ - and Myc-driven transcription program, facilitated by TNF $\alpha$, which distinctly controls metabolic activity in the two transitional B-cell subsets to allow negative selection in $\mathrm{T} 1^{21 / 23 \mathrm{DN}}$ and proliferation and differentiation in $\mathrm{T} 2{ }^{\mathrm{CD} 21 \text { int }} \mathrm{B}$-cells.

With the gain of survival and proliferation potential, $\mathrm{T} 2{ }^{\mathrm{CD}} 21 \mathrm{int}$ cells begin to express MHCII and its transcriptional activator, CIITA as well as the immune modulator Icosl. While the altered gene expression endows $\mathrm{T} 2{ }^{\mathrm{CD} 21 \text { int }}$ cells immune competence, it also prevents inadvertent B-cell mediated $\mathrm{T}$ cell activation, which can lead to autoimmune diseases (76). As T2 ${ }^{\mathrm{CD} 21 \text { int }}$ cells are poised for further differentiation in the splenic follicles, they express LT $\alpha$ and LT $\beta$ and facilitate follicular architecture and secondary lymphoid organogenesis (Table S1 in Supplementary Material) $(77,78)$.

Our analysis of CD45- $\mathrm{AP}^{-1-}$ mice revealed an increase in the percentage and numbers of total B-cells due to an increase in mature B-cells, particularly $\mathrm{MZ}$ type, similar to $\mathrm{CD} 45^{-1-}$ mice $(79,80)$. However, in contrast to CD45, CD45-AP appears to restrict transitional $\mathrm{B}$-cell differentiation, especially to $\mathrm{MZ} \mathrm{B}$ cell fate or it is required for maintaining homeostasis within the mature B-cell compartment. Additionally, reduced B220/CD45 surface expression in CD45-AP ${ }^{-/-}$B-cells suggested that CD45 and CD45-AP are reciprocally dependent for protein stability (8185). A reduction in CD45 and consequent phosphatase activity would reduce BCR signal strength. Despite conflicting reports concerning CD45-AP's role in receptor signaling (15, 81, 83, 86-89), we propose CD45-AP effects BCR signaling either in transitional cells to prevent their premature entry to the mature B-cell pool or their survival and proliferation. Thus, CD45-AP regulates splenic B-cell homeostasis (79).

Our transcriptome data showing significantly higher IL-9R together with high levels of heterodimer partner IL-2R $\gamma$ suggested a potential function for IL-9R in $\mathrm{MZ}^{\mathrm{CD} 9+} \mathrm{B}$-cells. While IL-9R did not play a role in MZ B-cell development, it may play a role in MZ B-cell function as exposure to IL-9 induced phosphorylation of Stat proteins. Activation of Stat proteins, particularly Stat3, is important in host defense (90). Consistently, overexpression of IL-9 has previously been shown to result in increased immunoglobulins before and after immunization (17, 44-46). These findings suggest a potential role for IL-9R-dependent activation of MZ B-cells in immune response (91). Although $\mathrm{MZ}^{\mathrm{CD} 9+}$ B-cells specialize in TI antibody responses, elevated IL-9R suggests that the TD antibody responses may also be differently regulated in this B-cell subset. Consistently, key regulators of antibody response in FO B-cells (IL-4R and IL-21R) are specifically down-regulated in MZ B-cells (Table S1 in Supplementary Material). 
A striking finding was that long-term activation of MZ Bcells by IL-9 in transgenic mice dramatically down-regulated CD9 surface levels possibly relating to its function in BCR signaling, migration, adhesion and homing (92-94). However, CD9 deficiency does not alter B-cell development or humoral immunity perhaps due to functional redundancy (95). Taken together, IL9/IL-9R induction of Stat pathway and down-regulation of CD9 suggests that IL-9R contributes to MZ B-cell function.

Accumulating evidence indicates MZ B-cells function in both innate and adaptive immunity (13) and we identified many DE transcripts with unknown functions in this subset. One such molecule was PAM, which has not been previously linked with MZ B-cell function. This E3 ubiquitin ligase mediates mTOR activation through sphingosine-1-phosphate receptors, of which S1p1 and S1p3 are both highly enriched in $\mathrm{MZ}^{\mathrm{CD} 9+}$ cells (Figure $5 \mathrm{~B}$ ) $(96,97)$. Given that mTOR promotes B-cell activation, maturation, antibody production, and survival, we speculate PAM bridges mTOR activation with sphingosine receptor signaling imparting $\mathrm{MZ}^{\mathrm{CD} 9+}$ with unique functionality (98). We provided evidence that $\mathrm{MZ}^{\mathrm{CD} 9+}$ cells possess unique innate sensing ability through expression of various PAMP receptors such as bactericidal Perforin-2. Further, we showed that TLR3 induction exclusively induced Perforin-2 in $\mathrm{MZ}^{\mathrm{CD} 9+}$ cells $(51,52)$. Thus, through a unique transcription program, $\mathrm{MZ}^{\mathrm{CD} 9+}$ cells become hardwired to recognize infectious agents and respond quickly to bridge the adaptive immune response.

In summary, our data have identified several genes and gene clusters, which have not previously been linked to specific splenic B-cell subsets. These data revealed potential novel developmental relationships among splenic B-cell populations, and indicated receptor revision in $\mathrm{T}^{21 / 23 \mathrm{DN}}$ may contribute to peripheral tolerance. The first major shift in the transcription program accompanied $\mathrm{T} 1^{21 / 23 \mathrm{DN}} \rightarrow \mathrm{T} 2^{\mathrm{CD} 21 \text { int }}$ differentiation, which was dominated by Myc and PI3K/Ras pathways indicating enhanced metabolic activity, survival (via $\mathrm{Bcl}-2$ ) and proliferation and these alterations were largely shared with mature B-cell subsets. Our analysis also demonstrated that CD45-AP is important for peripheral B-cell homeostasis while IL-9R participates in $\mathrm{MZ}^{\mathrm{CD} 9+}$ cell function. Highly selective expression and function of IL-9R suggests that in $\mathrm{MZ}^{\mathrm{CD} 9}+\mathrm{B}$-cells, TD antibody responses are regulated via mechanisms distinct from FO B-cells. Further, $\mathrm{MZ}^{\mathrm{CD} 9+}$ cells expressed genes that are known to confer innate effector functions as exemplified by expression of PAMPs, TLR3, and Perforin-2. Thus, $\mathrm{MZ}^{\mathrm{CD} 9+} \mathrm{B}$-cells are uniquely suited for TI antibody response, may distinctly regulate $\mathrm{TD}$ antibody response and possess broader innate immune capabilities than previously appreciated.

\section{AUTHOR CONTRIBUTIONS}

$\mathrm{EK}, \mathrm{KH}, \mathrm{AT}$, JR, and WK designed research; EK, $\mathrm{MH}, \mathrm{KH}, \mathrm{JL}$, IC, JW, and DD performed research; EK, DS, ESC, EC, and WK analyzed data; $\mathrm{KH}$ edited text; EK and WK wrote the paper.

\section{ACKNOWLEDGMENTS}

We would like to thank Dr. Oliver Umland (Diabetes Research Institute, University of Miami) for his expertise and help with flow cytometry and sorting experiments. We would also like to thank Dr. Lubov Nathanson and Dr. Yvonne Edwards for their help with preliminary analysis of NGS data as well as William Hulme for assisting in running NGS samples and processing raw data (all from Hussman Institute for Human Genomics, University of Miami). We would also like to thank James D. Kunzman for his help with "heatmap.2" function in R. This work was funded by National Institutes of Health grant RO1 AI060729 and University of Miami to WK. This work was also supported by the Fonds National de la Recherche Scientifique (FRS-FNRS, Belgium), and an Interuniversity Attraction Pole of the Belgian Federal Science Policy.

\section{SUPPLEMENTARY MATERIAL}

The Supplementary Material for this article can be found online at http://www.frontiersin.org/Journal/10.3389/fimmu.2015.00030/ abstract

\section{REFERENCES}

1. Nemazee D. Receptor editing in lymphocyte development and central tolerance. Nat Rev Immunol (2006) 6:728-40. doi:10.1038/nri1939

2. Loder F, Mutschler B, Ray RJ, Paige CJ, Sideras P, Torres R, et al. B cell development in the spleen takes place in discrete steps and is determined by the quality of B cell receptor-derived signals. J Exp Med (1999) 190:75-89. doi:10.1084/jem.190.1.75

3. Su TT, Rawlings DJ. Transitional B lymphocyte subsets operate as distinct checkpoints in murine splenic B cell development. J Immunol (2002) 168:2101-10. doi:10.4049/jimmunol.168.5.2101

4. Meyer-Bahlburg A, Andrews SF, Yu KO, Porcelli SA, Rawlings DJ. Characterization of a late transitional B cell population highly sensitive to BAFFmediated homeostatic proliferation. J Exp Med (2008) 205:155-68. doi:10.1084/ jem. 20071088

5. Petro JB, Gerstein RM, Lowe J, Carter RS, Shinners N, Khan WN. Transitional type 1 and $2 \mathrm{~B}$ lymphocyte subsets are differentially responsive to antigen receptor signaling. J Biol Chem (2002) 277:48009-19. doi:10.1074/jbc.M200305200

6. Hoek KL, Antony P, Lowe J, Shinners N, Sarmah B, Wente SR, et al. Transitional B cell fate is associated with developmental stage-specific regulation of diacylglycerol and calcium signaling upon B cell receptor engagement. J Immunol (2006) 177:5405-13. doi:10.4049/jimmunol.177.8.5405

7. Castro I, Wright JA, Damdinsuren B, Hoek KL, Carlesso G, Shinners NP, et al. $\mathrm{B}$ cell receptor-mediated sustained c-Rel activation facilitates late transitional B cell survival through control of B cell activating factor receptor and NF-kappaB2. J Immunol (2009) 182:7729-37. doi:10.4049/jimmunol.0803281

8. Giltiay NV, Chappell CP, Sun X, Kolhatkar N, Teal TH, Wiedeman AE, et al. Overexpression of TLR7 promotes cell-intrinsic expansion and autoantibody production by transitional T1 B cells. J Exp Med (2013) 210:2773-89. doi:10.1084/jem.20122798

9. Roy V, Chang NH, Cai Y, Bonventi G, Wither J. Aberrant IgM signaling promotes survival of transitional T1 B cells and prevents tolerance induction in lupus-prone New Zealand black mice. J Immunol (2005) 175:7363-71. doi:10.4049/jimmunol.175.11.7363

10. Kinnunen T, Chamberlain N, Morbach H, Cantaert T, Lynch M, PrestonHurlburt P, et al. Specific peripheral B cell tolerance defects in patients with multiple sclerosis. J Clin Invest (2013) 123:2737-41. doi:10.1172/JCI68775

11. Pillai S, Cariappa A. The follicular versus marginal zone B lymphocyte cell fate decision. Nat Rev Immunol (2009) 9:767-77. doi:10.1038/nri2656

12. Cinamon G, Zachariah MA, Lam OM, Foss FW Jr., Cyster JG. Follicular shuttling of marginal zone B cells facilitates antigen transport. Nat Immunol (2008) 9:54-62. doi:10.1038/ni1542

13. Cerutti A, Cols M, Puga I. Marginal zone B cells: virtues of innate-like antibodyproducing lymphocytes. Nat Rev Immunol (2013) 13:118-32. doi:10.1038/ nri3383

14. Cariappa A, Boboila C, Moran ST, Liu H, Shi HN, Pillai S. The recirculating B cell pool contains two functionally distinct, long-lived, posttransitional, follicular B cell populations. J Immunol (2007) 179:2270-81. doi:10.4049/jimmunol. 179.4.2270 
15. Takeda A, Matsuda A, Paul RM, Yaseen NR. CD45-associated protein inhibits CD45 dimerization and up-regulates its protein tyrosine phosphatase activity. Blood (2004) 103:3440-7. doi:10.1182/blood-2003-06-2083

16. Knoops L, Louahed J, Van Snick J, Renauld JC. IL-9 promotes but is not necessary for systemic anaphylaxis. J Immunol (2005) 175:335-41. doi:10.4049/jimmunol. 175.1.335

17. Vink A, Warnier G, Brombacher F, Renauld JC. Interleukin 9-induced in vivo expansion of the B-1 lymphocyte population. J Exp Med (1999) 189:1413-23. doi:10.1084/jem.189.9.1413

18. Hansen KD, Brenner SE, Dudoit S. Biases in Illumina transcriptome sequencing caused by random hexamer priming. Nucleic Acids Res (2010) 38:e131. doi:10.1093/nar/gkq224

19. Trapnell C, Roberts A, Goff L, Pertea G, Kim D, Kelley DR, et al. Differential gene and transcript expression analysis of RNA-seq experiments with TopHat and Cufflinks. Nat Protoc (2012) 7:562-78. doi:10.1038/nprot.2012.016

20. Tarazona S, Garcia-Alcalde F, Dopazo J, Ferrer A, Conesa A. Differential expression in RNA-seq: a matter of depth. Genome Res (2011) 21:2213-23. doi:10.1101/gr.124321.111

21. Huang da W, Sherman BT, Lempicki RA. Bioinformatics enrichment tools: paths toward the comprehensive functional analysis of large gene lists. Nucleic Acids Res (2009) 37:1-13. doi:10.1093/nar/gkn923

22. Huang da W, Sherman BT, Lempicki RA. Systematic and integrative analysis of large gene lists using DAVID bioinformatics resources. Nat Protoc (2009) 4:44-57. doi:10.1038/nprot.2008.211

23. Allman D, Lindsley RC, DeMuth W, Rudd K, Shinton SA, Hardy RR. Resolution of three nonproliferative immature splenic B cell subsets reveals multiple selection points during peripheral B cell maturation. J Immunol (2001) 167:6834-40. doi:10.4049/jimmunol.167.12.6834

24. Won WJ, Kearney JF. CD9 is a unique marker for marginal zone B cells, B1 cells, and plasma cells in mice. J Immunol (2002) 168:5605-11. doi:10.4049/ jimmunol.168.11.5605

25. Benitez A, Weldon AJ, Tatosyan L, Velkuru V, Lee S, Milford TA, et al. Differences in mouse and human nonmemory B cell pools. J Immunol (2014) 192:4610-9. doi:10.4049/jimmunol.1300692

26. Laurenti E, Doulatov S, Zandi S, Plumb I, Chen J, April C, et al. The transcriptional architecture of early human hematopoiesis identifies multilevel control of lymphoid commitment. Nat Immunol (2013) 14:756-63. doi:10.1038/ni.2615

27. Moroy T, Khandanpour C. Growth factor independence 1 (Gfil) as a regulator of lymphocyte development and activation. Semin Immunol (2011) 23:368-78. doi:10.1016/j.smim.2011.08.006

28. Suzuki N, Yoshioka N, Uekawa A, Matsumura N, Tozawa A, Koike J, et al. Transcription factor POU6F1 is important for proliferation of clear cell adenocarcinoma of the ovary and is a potential new molecular target. Int J Gynecol Cancer (2010) 20:212-9. doi:10.1111/IGC.0b013e3181c97ae0

29. Hoek KL, Gordy LE, Collins PL, Parekh VV, Aune TM, Joyce S, et al. Follicular B cell trafficking within the spleen actively restricts humoral immune responses. Immunity (2010) 33:254-65. doi:10.1016/j.immuni.2010.07.016

30. Wang HS, Feng JX, Qi CF, Li ZY, Morse HC, Clarke SH. Transitional B cells lose their ability to receptor edit but retain their potential for positive and negative selection. J Immunol (2007) 179:7544-52. doi:10.4049/jimmunol.179. 11.7544

31. Bretones G, Delgado MD, Leon J. Myc and cell cycle control. Biochim Biophys Acta (2014). doi:10.1016/j.bbagrm.2014.03.013

32. Tsai WB, Aiba I, Long Y, Lin HK, Feun L, Savaraj N, et al. Activation of Ras/PI3K/ERK pathway induces c-Myc stabilization to upregulate argininosuccinate synthetase, leading to arginine deiminase resistance in melanoma cells. Cancer Res (2012) 72:2622-33. doi:10.1158/0008-5472.CAN-11-3605

33. Zhu J, Blenis J, Yuan J. Activation of PI3K/Akt and MAPK pathways regulates Myc-mediated transcription by phosphorylating and promoting the degradation of Mad1. Proc Natl Acad Sci U S A (2008) 105:6584-9. doi:10.1073/pnas. 0802785105

34. Anzelon AN, Wu H, Rickert RC. Pten inactivation alters peripheral B lymphocyte fate and reconstitutes CD19 function. Nat Immunol (2003) 4:287-94 doi:10.1038/ni892

35. Arnold HK, Sears RC. Protein phosphatase 2A regulatory subunit B56alpha associates with c-myc and negatively regulates c-myc accumulation. Mol Cell Biol (2006) 26:2832-44. doi:10.1128/MCB.26.7.2832-2844.2006
36. Oeckinghaus A, Ghosh S. The NF-kappaB family of transcription factors and its regulation. Cold Spring Harb Perspect Biol (2009) 1:a000034. doi:10.1101/ cshperspect.a000034

37. Tsygankova OM, Prendergast GV, Puttaswamy K, Wang Y, Feldman MD, Wang $\mathrm{H}$, et al. Downregulation of RaplGAP contributes to Ras transformation. Mol Cell Biol (2007) 27:6647-58. doi:10.1128/MCB.00155-07

38. Vanhaesebroeck B, Stephens L, Hawkins P. PI3K signalling: the path to discovery and understanding. Nat Rev Mol Cell Biol (2012) 13:195-203. doi:10.1038/ nrm3290

39. Qiao G, Li Z, Molinero L, Alegre ML, Ying H, Sun Z, et al. T-cell receptor-induced NF-kappaB activation is negatively regulated by E3 ubiquitin ligase Cbl-b. $\mathrm{Mol}$ Cell Biol (2008) 28:2470-80. doi:10.1128/MCB.01505-07

40. von Bulow GU, van Deursen JM, Bram RJ. Regulation of the T-independent humoral response by TACI. Immunity (2001) 14:573-82. doi:10.1016/S10747613(01)00130-3

41. Dai X, James RG, Habib T, Singh S, Jackson S, Khim S, et al. A disease-associated PTPN22 variant promotes systemic autoimmunity in murine models. J Clin Invest (2013) 123:2024-36. doi:10.1172/JCI66963

42. Fousteri G, Liossis SN, Battaglia M. Roles of the protein tyrosine phosphatase PTPN22 in immunity and autoimmunity. Clin Immunol (2013) 149:556-65. doi:10.1016/j.clim.2013.10.006

43. Heng TS, Painter MW, Immunological Genome Project C. The immunological genome project: networks of gene expression in immune cells. Nat Immunol (2008) 9:1091-4. doi:10.1038/ni1008-1091

44. Knoops L, Louahed J, Renauld JC. IL-9-induced expansion of B-1b cells restores numbers but not function of B-1 lymphocytes in xid mice. J Immunol (2004) 172:6101-6. doi:10.4049/jimmunol.172.10.6101

45. Dugas B, Renauld JC, Pene J, Bonnefoy JY, Peti-Frere C, Braquet P, et al. Interleukin-9 potentiates the interleukin-4-induced immunoglobulin (IgG, IgM and IgE) production by normal human B lymphocytes. Eur J Immunol (1993) 23:1687-92. doi:10.1002/eji.1830230743

46. Petit-Frere C, Dugas B, Braquet P, Mencia-Huerta JM. Interleukin-9 potentiates the interleukin-4-induced IgE and IgG1 release from murine B lymphocytes. Immunology (1993) 79:146-51.

47. Faulkner H, Humphreys N, Renauld JC, Van Snick J, Grencis R. Interleukin-9 is involved in host protective immunity to intestinal nematode infection. Eur J Immunol (1997) 27:2536-40. doi:10.1002/eji.1830271011

48. Steenwinckel V, Louahed J, Orabona C, Huaux F, Warnier G, McKenzie A, et al. IL-13 mediates in vivo IL-9 activities on lung epithelial cells but not on hematopoietic cells. J Immunol (2007) 178:3244-51. doi:10.4049/jimmunol.178. 5.3244

49. Treml LS, Carlesso G, Hoek KL, Stadanlick JE, Kambayashi T, Bram RJ, et al. TLR stimulation modifies BLyS receptor expression in follicular and marginal zone B cells. J Immunol (2007) 178:7531-9. doi:10.4049/jimmunol.178.12.7531

50. Ranjan P, Bowzard JB, Schwerzmann JW, Jeisy-Scott V, Fujita T, Sambhara S. Cytoplasmic nucleic acid sensors in antiviral immunity. Trends Mol Med (2009) 15:359-68. doi:10.1016/j.molmed.2009.06.003

51. Mehrpour M, Esclatine A, Beau I, Codogno P. Overview of macroautophagy regulation in mammalian cells. Cell Res (2010) 20:748-62. doi:10.1038/cr.2010.82

52. McCormack R, de Armas LR, Shiratsuchi M, Ramos JE, Podack ER. Inhibition of intracellular bacterial replication in fibroblasts is dependent on the perforin-like protein (perforin-2) encoded by macrophage-expressed gene 1. J Innate Immun (2013) 5:185-94. doi:10.1159/000345249

53. Perwitasari O, Cho H, Diamond MS, Gale M Jr. Inhibitor of kappaB kinase epsilon (IKK(epsilon)), STAT1, and IFIT2 proteins define novel innate immune effector pathway against West Nile virus infection. J Biol Chem (2011) 286:44412-23. doi:10.1074/jbc.M111.285205

54. Spierings DC, McGoldrick D, Hamilton-Easton AM, Neale G, Murchison EP, Hannon GJ, et al. Ordered progression of stage-specific miRNA profiles in the mouse B2 B-cell lineage. Blood (2011) 117:5340-9. doi:10.1182/blood-201010-316034

55. Turchinovich G, Vu TT, Frommer F, Kranich J, Schmid S, Alles M, et al. Programming of marginal zone B-cell fate by basic Kruppel-like factor (BKLF/KLF3) Blood (2011) 117:3780-92. doi:10.1182/blood-2010-09-308742

56. Mabbott NA, Gray D. Identification of co-expressed gene signatures in mouse B1, marginal zone and B2 B-cell populations. Immunology (2014) 141:79-95. doi:10.1111/imm.12171 
57. Kin NW, Crawford DM, Liu J, Behrens TW, Kearney JF. DNA microarray gene expression profile of marginal zone versus follicular B cells and idiotype positive marginal zone B cells before and after immunization with Streptococcus pneumoniae. J Immunol (2008) 180:6663-74. doi:10.4049/jimmunol.180.10.6663

58. Debnath I, Roundy KM, Dunn DM, Weiss RB, Weis JJ, Weis JH. Defining a transcriptional fingerprint of murine splenic B-cell development. Genes Immun (2008) 9:706-20. doi:10.1038/gene.2008.70

59. Debnath I, Roundy KM, Weis JJ, Weis JH. Defining in vivo transcription factor complexes of the murine CD21 and CD23 genes. JImmunol (2007) 178:7139-50. doi:10.4049/jimmunol.178.11.7139

60. Carey JB, Moffatt-Blue CS, Watson LC, Gavin AL, Feeney AJ. Repertoire-based selection into the marginal zone compartment during B cell development. J Exp Med (2008) 205:2043-52. doi:10.1084/jem.20080559

61. Cariappa A, Tang M, Parng C, Nebelitskiy E, Carroll M, Georgopoulos K, et al. The follicular versus marginal zone B lymphocyte cell fate decision is regulated by Aiolos, Btk, and CD21. Immunity (2001) 14:603-15. doi:10.1016/S10747613(01)00135-2

62. Guerrier T, Youinou P, Pers JO, Jamin C. TLR9 drives the development of transitional B cells towards the marginal zone pathway and promotes autoimmunity. J Autoimmun (2012) 39:173-9. doi:10.1016/j.jaut.2012.05.012

63. Labi V, Erlacher M, Kiessling S, Manzl C, Frenzel A, O’Reilly L, et al. Loss of the BH3-only protein Bmf impairs B cell homeostasis and accelerates gamma irradiation-induced thymic lymphoma development. J Exp Med (2008) 205:641-55. doi:10.1084/jem.20071658

64. Karnell FG, Brezski RJ, King LB, Silverman MA, Monroe JG. Membrane cholesterol content accounts for developmental differences in surface B cell receptor compartmentalization and signaling. J Biol Chem (2005) 280:25621-8. doi:10.1074/jbc.M503162200

65. Gelman IH. Emerging roles for SSeCKS/Gravin/AKAP12 in the control of cell proliferation, cancer malignancy, and barriergenesis. Genes Cancer (2010) 1:1147-56. doi:10.1177/1947601910392984

66. Smarda J, Sugarman J, Glass C, Lipsick J. Retinoic acid receptor alpha suppresses transformation by v-myb. Mol Cell Biol (1995) 15:2474-81.

67. Knoepfler PS. Myc goes global: new tricks for an old oncogene. Cancer Res (2007) 67:5061-3. doi:10.1158/0008-5472.CAN-07-0426

68. Wang R, Dillon CP, Shi LZ, Milasta S, Carter R, Finkelstein D, et al. The transcription factor Myc controls metabolic reprogramming upon $\mathrm{T}$ lymphocyte activation. Immunity (2011) 35:871-82. doi:10.1016/j.immuni.2011.09.021

69. Iritani BM, Eisenman RN. c-Myc enhances protein synthesis and cell size during B lymphocyte development. Proc Natl Acad Sci U S A (1999) 96:13180-5. doi:10.1073/pnas.96.23.13180

70. Poutanen M, Huhtaniemi I, Bjorkgren I. Loss of Bmyc results in increased apoptosis associated with upregulation of Myc expression in juvenile murine testis. Reproduction (2012) 144:495-503. doi:10.1530/REP-11-0444

71. Lanier LL. DAP10- and DAP12-associated receptors in innate immunity. Immunol Rev (2009) 227:150-60. doi:10.1111/j.1600-065X.2008.00720.x

72. Li DH, Winslow MM, Cao TM, Chen AH, Davis CR, Mellins ED, et al. Modulation of peripheral B cell tolerance by CD72 in a murine model. Arthritis Rheum (2008) 58:3192-204. doi:10.1002/art.23812

73. Aukema SM, Siebert R, Schuuring E, van Imhoff GW, Kluin-Nelemans HC, Boerma EJ, et al. Double-hit B-cell lymphomas. Blood (2011) 117:2319-31. doi:10.1182/blood-2010-09-297879

74. Bissonnette RP, Echeverri F, Mahboubi A, Green DR. Apoptotic cell death induced by c-myc is inhibited by bcl-2. Nature (1992) 359:552-4. doi:10.1038/ 359552a0

75. Faustman D, Davis M. TNF receptor 2 pathway: drug target for autoimmune diseases. Nat Rev Drug Discov (2010) 9:482-93. doi:10.1038/nrd3030

76. Hamel KM, Cao Y, Olalekan SA, Finnegan A. B cell-specific expression of inducible costimulator ligand is necessary for the induction of arthritis in mice. Arthritis Rheumatol (2014) 66:60-7. doi:10.1002/art.38207

77. Ettinger R, Mebius R, Browning JL, Michie SA, van Tuijl S, Kraal G, et al. Effects of tumor necrosis factor and lymphotoxin on peripheral lymphoid tissue development. Int Immunol (1998) 10:727-41. doi:10.1093/intimm/10.6.727

78. Korner H, Cook M, Riminton DS, Lemckert FA, Hoek RM, Ledermann B, et al. Distinct roles for lymphotoxin-alpha and tumor necrosis factor in organogenesis and spatial organization of lymphoid tissue. Eur J Immunol (1997) 27:2600-9. doi:10.1002/eji.1830271020
79. Zhu JW, Brdicka T, Katsumoto TR, Lin J, Weiss A. Structurally distinct phosphatases CD45 and CD148 both regulate B cell and macrophage immunoreceptor signaling. Immunity (2008) 28:183-96. doi:10.1016/j.immuni. 2007.11.024

80. Hermiston ML, Tan AL, Gupta VA, Majeti R, Weiss A. The juxtamembrane wedge negatively regulates CD45 function in B cells. Immunity (2005) 23:635-47. doi:10.1016/j.immuni.2005.11.001

81. Leitenberg D, Falahati R, Lu DD, Takeda A. CD45-associated protein promotes the response of primary CD4 T cells to low-potency T-cell receptor (TCR) stimulation and facilitates CD45 association with CD3/TCR and lck. Immunology (2007) 121:545-54. doi:10.1111/j.1365-2567.2007.02602.x

82. Ding I, Bruyns E, Li P, Magada D, Paskind M, Rodman L, et al. Biochemical and functional analysis of mice deficient in expression of the CD45-associated phosphoprotein LPAP. Eur J Immunol (1999) 29:3956-61. doi:10.1002/(SICI) 1521-4141(199912)29:12<3956::AID-IMMU3956>3.0.CO;2-G

83. Matsuda A, Motoya S, Kimura S, McInnis R, Maizel AL, Takeda A. Disruption of lymphocyte function and signaling in CD45-associated protein-null mice. J Exp Med (1998) 187:1863-70. doi:10.1084/jem.187.11.1863

84. Cahir McFarland ED, Pingel J, Thomas ML. Definition of amino acids sufficient for plasma membrane association of CD45 and CD45-associated protein. Biochemistry (1997) 36:7169-75. doi:10.1021/bi970013y

85. Kitamura K, Matsuda A, Motoya S, Takeda A. CD45-associated protein is a lymphocyte-specific membrane protein expressed in two distinct forms. Eur J Immunol (1997) 27:383-8. doi:10.1002/eji.1830270207

86. Motoya S, Kitamura K, Matsuda A, Maizel AL, Yamamoto H, Takeda A. Interaction between CD45-AP and protein-tyrosine kinases involved in T cell receptor signaling. J Biol Chem (1999) 274:1407-14. doi:10.1074/jbc.274.3.1407

87. Cahir McFarland ED, Thomas ML. CD45 protein-tyrosine phosphatase associates with the WW domain-containing protein, CD45AP, through the transmembrane region. J Biol Chem (1995) 270:28103-7. doi:10.1074/jbc.270.47. 28103

88. Veillette A, Soussou D, Latour S, Davidson D, Gervais FG. Interactions of CD45-associated protein with the antigen receptor signaling machinery in T-lymphocytes. J Biol Chem (1999) 274:14392-9. doi:10.1074/ jbc.274.20.14392

89. Kung C, Okumura M, Seavitt JR, Noll ME, White LS, Pingel JT, et al. CD45associated protein is not essential for the regulation of antigen receptor-mediated signal transduction. Eur J Immunol (1999) 29:3951-5. doi:10.1002/(SICI)15214141(199912)29:12<3951::AID-IMMU3951>3.0.CO;2-9

90. Welte T, Zhang SS, Wang T, Zhang Z, Hesslein DG, Yin Z, et al. STAT3 deletion during hematopoiesis causes Crohn's disease-like pathogenesis and lethality: a critical role of STAT3 in innate immunity. Proc Natl Acad Sci U S A (2003) 100:1879-84. doi:10.1073/pnas.0237137100

91. Grohmann U, Van Snick J, Campanile F, Silla S, Giampietri A, Vacca C, et al. IL-9 protects mice from Gram-negative bacterial shock: suppression of TNFalpha, IL-12, and IFN-gamma, and induction of IL-10. J Immunol (2000) 164:4197-203. doi:10.4049/jimmunol.164.8.4197

92. Claas C, Stipp CS, Hemler ME. Evaluation of prototype transmembrane 4 superfamily protein complexes and their relation to lipid rafts. J Biol Chem (2001) 276:7974-84. doi:10.1074/jbc.M008650200

93. Le Naour F, Andre M, Boucheix C, Rubinstein E. Membrane microdomains and proteomics: lessons from tetraspanin microdomains and comparison with lipid rafts. Proteomics (2006) 6:6447-54. doi:10.1002/pmic.200600282

94. Leung KT, Chan KY, Ng PC, Lau TK, Chiu WM, Tsang KS, et al. The tetraspanin CD9 regulates migration, adhesion, and homing of human cord blood CD34+ hematopoietic stem and progenitor cells. Blood (2011) 117:1840-50. doi:10. 1182/blood-2010-04-281329

95. Cariappa A, Shoham T, Liu H, Levy S, Boucheix C, Pillai S. The CD9 tetraspanin is not required for the development of peripheral B cells or for humoral immunity. J Immunol (2005) 175:2925-30. doi:10.4049/jimmunol.175.5.2925

96. Maeurer C, Holland S, Pierre S, Potstada W, Scholich K. Sphingosine-1phosphate induced mTOR-activation is mediated by the E3-ubiquitin ligase PAM. Cell Signal (2009) 21:293-300. doi:10.1016/j.cellsig.2008.10.016

97. Han S, Witt RM, Santos TM, Polizzano C, Sabatini BL, Ramesh V. Pam (Protein associated with $\mathrm{Myc}$ ) functions as an E3 Ubiquitin ligase and regulates TSC/mTOR signaling. Cell Signal (2008) 20:1084-91. doi:10.1016/j.cellsig.2008. 01.020 
98. Powell JD, Pollizzi KN, Heikamp EB, Horton MR. Regulation of immune responses by mTOR. Annu Rev Immunol (2012) 30:39-68. doi:10.1146/annurevimmunol-020711-075024

Conflict of Interest Statement: The authors declare that the research was conducted in the absence of any commercial or financial relationships that could be construed as a potential conflict of interest.

Received: 11 November 2014; accepted: 15 January 2015; published online: 11 February 2015.

Citation: Kleiman E, Salyakina D, De Heusch M, Hoek KL, Llanes JM, Castro I, Wright JA, Clark ES, Dykxhoorn DM, Capobianco E, Takeda A, McCormack
RM, Podack ER, Renauld J-C and Khan WN (2015) Distinct transcriptomic features are associated with transitional and mature B-cell populations in the mouse spleen. Front. Immunol. 6:30. doi: 10.3389/fimmu.2015.00030

This article was submitted to B Cell Biology, a section of the journal Frontiers in Immunology.

Copyright (c) 2015 Kleiman, Salyakina, De Heusch, Hoek, Llanes, Castro, Wright, Clark, Dykxhoorn, Capobianco, Takeda, McCormack, Podack, Renauld and Khan. This is an open-acces article distributed under the terms of the Creative Commons Attribution License (CC BY). The use, distribution or reproduction in other forums is permitted, provided the original author(s) or licensor are credited and that the original publication in this journal is cited, in accordance with accepted academic practice. No use, distribution or reproduction is permitted which does not comply with these terms. 